\title{
中印中成药功效语的翻译问题分析
}

\section{ANALISIS KESALAHAN PENERJEMAHAN MANDARIN INDONESIA PADA KHASIAT OBAT JADI TIONGKOK}

\author{
JULIANA, BA., MTCSOL \\ Program Studi Bahasa dan Budaya Tionghoa, Universitas Bunda Mulia \\ Email : Yunshiang168@gmail.com
}

\begin{abstract}
摘要
中药在我们现在日常生活中已经非常常见的东西了, 尤其中成药非常便捷所以为 了能够使更多的印尼人使用中成药, 需要一个翻译过程, 特别是功效语。

本论研究对象是五家中成药进口公司的进口药品, 共 120 个中成药品, 盒子上必 须出现中文版与印尼版的功效语, 而药品必须在两个国家公用, 并且得到印度尼西亚 食品与药物监督机构批准。

本研究的研究目的得知翻译药物功效语中出现哪些翻译问题。据调查研究, 笔者 发现中成药功效语翻译里存在着三大问题, 即减译问题、增译问题和误译问题, 而最 常见的中成药功效语翻译问题是减译问题, 占 $63.8 \%$, 因为这样的翻译显出更简介, 但 并不能把原文的信息明确地翻译出来，使有些病症发生了意义上的变化。笔者建议， 在翻译功效语中, 最好采取直译技巧, 因为这样能把原文的消息明确地翻译出来, 以 免消费者对药品使用产生误会。
\end{abstract}

关键词: 中成药、功效语翻译、翻译问题

\begin{abstract}
Abstrak
Pengobatan tradisional Tiongkok merupakan hal yang sangat lazim dalam kehidupan kita sehari-hari, apalagi pengobatan obat jadi Tiongkok yang sangat nyaman dipergunakan oleh masyarakat umum, sehingga agar lebih banyak masyarakat Indonesia yang dapat menggunakan obat jadi Tiongkok diperlukan proses penerjemahan terutama pada khasiat obat tersebut.

Subjek karya penulisan ini adalah 120 buah obat jadi Tiongkok dari 5 perusahaan importir obat jadi Tiongkok, yang dimana pada kotak obat harus tercantum khasiat obat dalam bahasa Mandarin dan bahasa Indonesia, dan obat-obatan tersebut ada di kedua negara, serta telah terdaftar di Badan Pengawasan Obat dan Makanan Indonesia.

Tujuan dari karya penulisan ini adalah untuk mengetahui masalah apa saja yang muncul dalam menerjemahkan obat. Berdasarkan analisa, peneliti menyadari dalam menerjemahkan khasiat obat terdapat tiga masalah utama penerjemahan, yaitu masalah teknik pengurangan
\end{abstract}


kata, masalah teknik penambahan kata dan masalah distorsi makna, sedangkan masalah yang paling sering muncul adalah masalah teknik pengurangan kata dengan persentase $63.8 \%$, karena dengan teknik terjemahan ini khasiat obat akan terlihat lebih singkat. Namun, menerjemahkan dengan teknik ini tidak terlalu baik karena informasi aslinya tidak diterjemahkan dengan tepat, bahkan ada beberapa yang mengalami perubahan makna. Penulis menyadari bahwa dalam menerjemahkan khasiat obat, paling baik menggunakan teknik terjemahan literal, karena informasi aslinya dapat diterjemahkan dengan tepat, dan konsumen tidak akan salah paham ketika menggunakan obat.

Kata kunci : Obat Tiongkok ; Teknik Penerjemahan Khasiat Obat ; Kesalahan Terjemahan

\section{一 引言}

随着改革开放的不断深化, 经济的快速发展, 中国如今吸引了全世界的目光。越 来越多的中国产品进入了国际市场。作为中华传统文化的瑰宝, 中草药一直是中国产 品与文化中不可缺的组成部分。近年来, 中药吸引了全世界的关注和兴趣。包括印尼 华人众多的地方。在印尼也越来越多的人使用中药和中成药, 但是为了能够让广大印 尼消费者能够认识和相信中药和中成药, 需要把中文中成药的功效语翻译到印尼语功 效语，使广大印尼消费者可以方便使用。因为不是所有印尼人都能读中文功效语。

一个准确地功效语翻译是一个非常关键工程。因此, 能准确地翻译功效语不仅会 提高药店的销售，甚至会提高消费者对药品的信心。

笔者也是中成药消费者之一, 在消费过程中经常发现中成药的翻译中往往出现不规 范的现象, 不但不能够很好地传达中成药的信息与功效, 还常常引起消费者误会。因 此笔者选择了中成药功效语作为为研究题目, 以中成药功效语翻译为研究对象。笔者 希望通过次研究能够了解到中成药功效语翻译中存在着哪些翻译问题。

\section{二 研究方法}

笔者收集了五家进口药公司一共收集了 120 中成药的功效语作为研究语料，有 Saras Subur Abadi, Intra Aries, Perdana Sakti, Sinar Herba Radix 和 Salim Trading 公司, 但是每个公司不平均, 因为有些公司的药种比较多, 而有些公司的药种比较少。从 Saras Subur Abadi 收集了 40 种中成药、Intra Aries 收集了 40 种中成药、Perdana Sakti 收集了 
20 种中成药、Sinar Herba Radix 收集了 15 种中成药和 Salim Trading 收集了 5 种中成药。 每种中成药的盒子上必须写上中文版与印尼版的功效语, 而每药品必须在两个国家公 用，并且得到印度尼西亚食品与药物监督机构批准。

之后仔细阅读中成药的功效语的翻译并分析及对比中文版的功效语与印尼版的。最 后使用相关的理论把收集到的语料找出翻译出现的问题及在翻译问题中提出比较正确 的翻译。

\section{三 研究结果及讨论}

通过笔者从五家中成药进口公司收集了 120 中成药的功效语, 经统计结果, 得出以 下的结论:

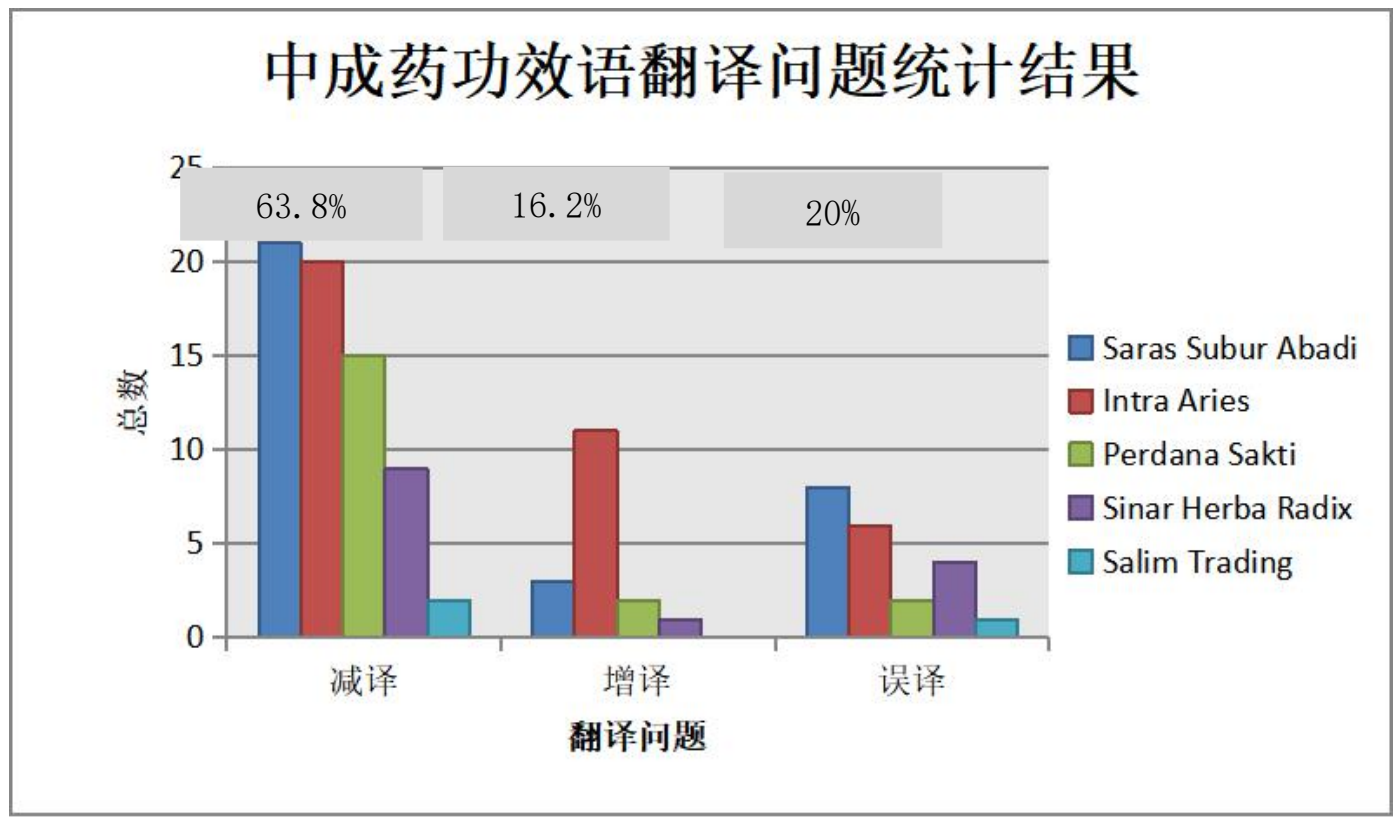

图 3-1

从表格上可以得知中成药翻译存在着三大问题即减译问题、增译问题和误译问题， 而最常见的问题是减译问题，占 $63.8 \%$ 。之所以减译翻译技巧最多的原因，笔者认为如 果使用直译技巧会显得复杂并太长了，但是假如使用减译技巧虽然会显得比较简短， 可是翻译之后的功效语已经不完整了，甚至有些发生了意义变化，还会造成消费者的 误会。

为了更详细中成药翻译存在的三大问题进行详细分析, 以下笔者举几个例子作为例 子。 


\section{1 减译}

表 3.1：表格 1

\begin{tabular}{|l|l|}
\hline \multicolumn{2}{|c|}{ 例子 1: 步长头痛宁胶囊功效语 } \\
\hline 原文 & 译文 \\
\hline 功能主治: & Khasiat: \\
熄风涤痰, 逐瘀止痛。用于偏头痛, \\
紧张性头痛属痰瘀阻络证, 证见: 痛 \\
势甚剧, 或攻冲作痛, 或痛如雉刺, \\
或连及目齿, 伴目眩畏光, 胸闪脘胀, \\
恶心呕吐, 急躁易怒, 反复发作。
\end{tabular}

在上面的功效语中, 很明显可以看出很多功效语是没有被翻译出来, 使译文中少了 很多信息，如 “熄风涤痰，逐瘀止痛” 和 “紧张性头痛属痰瘀阻络证，证见：痛势甚 剧, 或攻冲作痛, 或痛如雉刺, 或连及目齿, 伴目眩畏光, 胸闷脘胀, 恶心呕吐, 急 躁易怒，反复发作”。在译语那些功效语的翻译如下：“熄风涤痰，逐瘀止 痛” “Meredakan pusing, demam tinggi, epilepsi, mengurangi dahak, melancarkan peredaran darah dan mengurangi rasa sakit. 和 “紧张性头痛属痰瘀阻络证, 证见：痛 势甚剧, 或攻冲作痛, 或痛如雉刺, 或连及目齿, 伴目眩畏光, 胸问脘胀, 恶心呕吐, 急躁易怒, 反复发作” “Digunakan untuk sakit kepala sebelah (migrain), sakit kepala karena tegang dengan gejala: sakit yang sangat intens, atau seperti dipukul atau sakit seperti ditusuk-tusuk atau sampai ke daerah mata dan gigi, disertai pusing dan sensitif terhadap cahaya, sesak di dada, mual dan muntah, sakitnya tidak tertahankan, sakitnya berulang-ulang.'

在译文中被减掉的原文翻译导致药物消费者得到的信息不是完整的。这对无法读 中文的消费者是有害无利。 
表3.1：表格 2

\begin{tabular}{|c|c|}
\hline \multicolumn{2}{|c|}{ 例子 2 伤湿止痛膏 } \\
\hline 原文 & 译文 \\
\hline $\begin{array}{l}\text { 功能主治: } \\
\text { 风寒疼痛, 筋骨酸痛, 肩酸腰痛, 关 } \\
\text { 节痛, 肌肉痛, 扭伤, 跌打损伤。 }\end{array}$ & $\begin{array}{l}\text { Khasiat: } \\
\text { Membantu meredakan keseleo, nyeri } \\
\text { otot pinggang dan punggung. }\end{array}$ \\
\hline
\end{tabular}

根据例子 2 表格的功效语，我们可以看到有些功效语是没有翻译出来的。译文只 翻译 “肩酸腰痛” 和 “扭伤” 其他的 “风寒疼痛, 筋骨酸痛” “Membantu meredakan nyeri akibat angin, dan tulang' 、“关节痛, 肌肉痛” “nyeri sendi, nyeri otot' 和 “跌 打损伤” “memar'。没有翻译出来。其实从译文中我们可以知道此药品还有其他的功 效和作用，如果消费者不懂中文就无法知道全部的功效信息。从此可以知道减译技巧 不能达到一个很好的翻译效果。

\section{2 增译}

表 3.2: 表格 3

\begin{tabular}{|l|l|}
\hline \multicolumn{2}{|c|}{ 例子 3 补中益气丸功效语 } \\
\hline 原文 & 译文 \\
\hline 功能主治: & Khasiat: \\
补中益气。用于体倦乏力, 内脏下 & $\begin{array}{l}\text { Membantu memelihara kesehatan } \\
\text { limpa dan membantu memelihara } \\
\text { 垂。。 }\end{array}$ \\
\hline
\end{tabular}

根据例子 3 表格中的功效语中, 我们可以发现增加了一下原文中没有的， “membantu memelihara kesehatan pencernaan.' 在原文中并没有此功效。增加了一些不 是药品的功效信息。其实这样反而会误导消费者，尤其对那些完全不懂中文的消费者。 
笔者认为应该翻译成: Memelihara kesehatan limpa dan maag, digunakan untuk mengatasi tubuh letih dan lesu, turun berok (hernia).

表 3.3: 表格 4

\begin{tabular}{|l|l|}
\hline \multicolumn{2}{|c|}{ 例子 $\mathbf{4}$ 强力银赖片功效语 } \\
\hline 原文 & 译文 \\
\hline 功能与主治: & Khasiat: \\
清热解毒、辛凉、解表。 & $\begin{array}{l}\text { Membantu meredakan demam, } \\
\text { pilek, dan sakit tenggorokan. }\end{array}$ \\
\hline
\end{tabular}

从例子 4 的功效语中, 我们可以发现增加了 'sakit tenggorokan', 加上在中文功 效语中根本没有的功效。这样对不懂中文的消费者接受错误的信息。笔者应该翻译： Membantu meredakan demam, mengatasi influenza, dan keringat dingin.

3.3 误译

表 3.4: 表格 5

\begin{tabular}{|l|l|}
\hline \multicolumn{2}{|c|}{ 例子 5 复方阿胶浆功效语 } \\
\hline 原文 & 译文 \\
\hline 功能主治: & Khasiat: \\
补气养血。用于头晕, 失眠、心悸、 & Membantu memelihara stamina. \\
贫血。 & \\
\hline
\end{tabular}

从例子 5 的功效语中的翻译文本中, 可以很明显看出是误译。，译者在译文中将 “补气养血。用于头晕, 失眠、心悸、贫血。”这些功效语直接翻译成 'Membantu memelihara stamina' 。这个完全改变了原文的意义。笔者认为可以翻译成 'Membantu menambah trombosit darah, digunakan untuk kepala pusing, sulit tidur, jantung berdebar kencang tidak beraturan dan anemia.' 
表3.5: 表格6

\begin{tabular}{|l|l|}
\hline \multicolumn{2}{|c|}{ 例子 6 保济丸功效语 } \\
\hline 原文 & 译文 \\
\hline 功能主治: & Khasiat: \\
解表, 祛湿, 和中。用于暑湿感冒, & Membantu memelihara kesehatan \\
症见发热头痛、腹痛腹泻、恶心呕吐、 & pencernaan. \\
肠胃不适; 亦可用于晕车晕船。 & \\
\hline
\end{tabular}

在译文中出现的误译问题，不仅会导源语的信息和译文不一致，而且还导致消费 者接受不正确的功效语的信息。

在例子 6 的功效语中的翻译文本中, 可以很明显看出是误译。译者在译文中把 “解 表, 祛湿, 和中。用于暑湿感冒, 症见发热头痛、腹痛腹泻、恶心呕吐、肠胃不适; 亦可用于晕车晕船。”直接翻译成 “Membantu memelihara kesehatan pencernaan.' 这 个完全改变了原文的意义了。笔者认为可以翻译成 “Mengurangi kelembaban pada nafas (yang menyebabkan kantuk dan menurunkan kinerja tubuh). Digunakan untuk flu, gejala deman, sakit kepala, nyeri perut dan diare, mual dan muntah, gangguan usus dan maag, juga bisa digunakan untuk mabuk perjalanan dan mabuk laut.

在译文中出现的误译问题，不仅会导源语的信息和译文不一致，而且还导致消费 者接受不正确的功效语的信息。

\section{4 小结}

为了更方便大家看，笔者把所有的药品列表格和提出建议翻译。

\section{Saras Subur Abadi 的药品建议翻译}

\begin{tabular}{|l|l|}
\hline 1 & 小活络丸 \\
& 翻译问题: 减译 \\
& 源语: 祛风除湿, 活络通痹。 \\
& $\begin{array}{l}\text { 译语: Membantu meredakan nyeri pada persendian. } \\
\text { 建议翻译: Membantu meredakan nyeri pada persendian dan melancarkan sirkulasi } \\
\quad \text { darah. }\end{array}$ \\
\hline 2 & 消石片 \\
\hline
\end{tabular}




\begin{tabular}{|c|c|}
\hline & $\begin{array}{l}\text { 翻译问题: 减译 } \\
\text { 源语: 清热通淋, 止痛排石。用于肾结石、尿道结石、膀胱结石、输尿管结石属 } \\
\text { 热淋证者。 } \\
\text { 译语: Secara tradisional digunakan untuk membantu meluruhkan batu di ginjal dan } \\
\text { saluran kemih. } \\
\text { 建议翻 译: Secara tradisional digunakan untuk meredakan panas serta membantu } \\
\text { meluruhkan batu di ginjal dan saluran kemih. Digunakan untuk penderita } \\
\text { batu ginjal, batu uretra, batu kandung kemih, batu ureter. }\end{array}$ \\
\hline כ & $\begin{array}{l}\text { 穿心莲 } \\
\text { 翻译问题: 减译 } \\
\text { 源语: 清热解毒, 利湿。用于风热感冒, 咽喉疼痛, 湿热泄泻。 } \\
\text { 译语: Membantu meredakan panas yang disertai tenggorokan kering. } \\
\text { 建 议翻 译: Membantu meredakan panas, dan mengatasi peradangan. Digunakan } \\
\quad \text { untuk orang yang terkena demam, sakit tenggorokan, diare akibat daerah } \\
\quad \text { yang panas dan lembab. }\end{array}$ \\
\hline & $\begin{array}{l}\text { 正天丸 } \\
\text { 翻译问题: 减译 } \\
\text { 源语: 疏风活血, 养血平肝, 通络止痛。用于外感风邪、病血阻络、血虚失养、 } \\
\text { 肝阳上六引起的偏头痛、紧张性头痛、神经性头痛、颈椎病型头痛、经前 } \\
\text { 头痛。 } \\
\text { 译 语 : Membantu meredakan sakit kepala dan secara tradisional membantu } \\
\text { memperbaiki sirkulasi darah. } \\
\text { 建议翻译: Membantu memperbaiki sirkulasi darah, menyehatkan fungsi hati, dan } \\
\text { meredakan sakit. Digunakan untuk orang yang sakit kepala migran, sakit } \\
\text { kepala akibat tegang, sakit kepala akibat trigeminal neuralgia (gangguan } \\
\text { syaraf), sakit kepala akibat nyeri pada leher, serta sakit kepala akibat } \\
\text { sedang datang bulan. }\end{array}$ \\
\hline & $\begin{array}{l}\text { 明目地黄丸 } \\
\text { 翻译问题: 减译 } \\
\text { 源语: 滋肾养肝, 明目。用于肝肾阴虚, 目涩畏光, 视物模糊, 迎风流泪。 } \\
\text { 译语: Secara tradisional membantu memelihara kesehatan mata. } \\
\text { 建 议 翻 译 : Secara tradisional membantu menguatkan ginjal dan hati, serta } \\
\text { mempertajam penglihatan. Digunakan untuk kurangnya cairan pada hati } \\
\quad \text { dan ginjal, mata yang takut sinar/silau, penglihatan kabur, dan mata } \\
\text { berair bila terkena angin. }\end{array}$ \\
\hline 6 & $\begin{array}{l}\text { 步长头痛宁胶囊 } \\
\text { 翻译问题: 减译 } \\
\text { 源语: 熄风涤痰, 逐瘀止痛。用于偏头痛, 紧张性头痛属痰瘀阻络证, 证见: 痛 }\end{array}$ \\
\hline
\end{tabular}




\begin{tabular}{|c|c|}
\hline & $\begin{array}{l}\text { 势甚剧, 或攻冲作痛, 或痛如雉刺, 或连及目齿, 伴目眩畏光, 胸闷脘胀, } \\
\text { 恶心呕吐, 急躁易怒, 反复发作。 } \\
\text { 译语: Membantu meredakan sakit kepala. } \\
\text { 建 议 翻 译 : Meredakan pusing, demam tinggi, epilepsi, mengurangi dahak, } \\
\text { melancarkan peredaran darah dan mengurangi rasa sakit. Digunakan } \\
\text { untuk sakit kepala sebelah (migrain), sakit kepala karena tegang dengan } \\
\text { gejala : sakit yang sangat intens, atau seperti dipukul atau sakit seperti } \\
\text { ditusuk-tusuk atau sampai ke daerah mata dan gigi, disertai pusing dan } \\
\text { sensitif terhadap cahaya, sesak di dada, mual dan muntah, sakitnya tidak } \\
\text { tertahankan, sakitnya berulang-ulang. }\end{array}$ \\
\hline 7 & $\begin{array}{l}\text { 清音丸 } \\
\text { 翻译问题: 减译 } \\
\text { 源语: 帮助缓解咳嗽和喉咙干痒。 } \\
\text { 译语: Membantu meredakan batuk dan tenggorokan kering. } \\
\text { 建议翻译: Membantu meredakan batuk dan tenggorokan kering serta gatal. }\end{array}$ \\
\hline 8 & $\begin{array}{l}\text { 健脾丸 } \\
\text { 翻译问题: 减译 } \\
\text { 源语: 健脾开胃。用于脾胃虚弱, 脘腹胀满, 食少便溏。 } \\
\text { 译语: Membantu memperbaiki nafsu makan. } \\
\text { 建 议翻 译: Membantu memperkuat fungsi limpa dan memperbaiki nafsu makan. } \\
\quad \begin{array}{l}\text { Digunakan untuk gangguan pencernaan lemah, perut kembung, serta sulit } \\
\quad \text { mencerna makanan. }\end{array}\end{array}$ \\
\hline 9 & $\begin{array}{l}\text { 正骨水 } \\
\text { 翻译问题: 减译 } \\
\text { 源语: 活血社疼, 舒筋活络, 消肿止痛。用于跌打扭伤以及体育运动前后消除疲 } \\
\quad \text { 劳。 } \\
\text { 译语: Membantu meringankan luka. } \\
\text { 建议翻 译: Mengaktifkan aliran darah dan chi, menenangkan syaraf, meredakan } \\
\quad \text { bengkak dan meredakan rasa sakit. Digunakan untuk luka memar karena } \\
\quad \text { jatuh/terbentur, serta mengurangi rasa lelah otot setelah berolahraga. }\end{array}$ \\
\hline 10 & $\begin{array}{l}\text { 深海龙胶囊 } \\
\text { 翻译问题: 减译 } \\
\text { 源语: 温补肾阳, 补髓填精。用于因肾阳不足所致的腰膝酸软, 畏寒肢冷, 神疲 } \\
\text { 乏力, 头晕耳鸣, 心悸失眠, 小便频数。 } \\
\text { 译语: Membantu memelihara kesehatan fungsi ginjal. } \\
\text { 建议翻译: Membantu memelihara kesehatan fungsi ginjal, mengisi kembali sumsum, } \\
\quad \text { digunakan untuk mengurangi rasa sakit pada pinggang dan lutut akibat } \\
\quad \text { gangguan ginjal, menggigil, tidak semangat dan lesu, pusing dan telinga }\end{array}$ \\
\hline
\end{tabular}




\begin{tabular}{|c|c|}
\hline & $\begin{array}{l}\text { berdengung, jantung berdebar dan insomnia, gangguan frekuensi buang } \\
\text { air kecil. }\end{array}$ \\
\hline 11 & $\begin{array}{l}\text { 稳心颗粒 } \\
\text { 翻译问题: 减译 } \\
\text { 源语: 益气养阴, 活血化瘀。用于气阴两虚, 心脉瘀阻所致的心悸不宁、气短乏 } \\
\text { 力、胸闷胸痛; 室性早搏、房性早搏见上述证候者。 } \\
\text { 译语: Secara tradisional digunakan untuk membantu sirkulasi darah. } \\
\text { 建议翻译: Memperbaiki aliran chi dan yin, melancarkan aliran darah. Digunakan } \\
\text { untuk memperbaiki gangguan detak jantung (jantung berdebar), nafas } \\
\quad \text { pendek dan rasa lemas, sesak dan nyeri dada, gangguan detak jantung } \\
\quad \text { yang menyebabkan jantung berdetak secara tidak biasa (kontraksi } \\
\text { ventrikel prematur), untuk kontraksi atrium prematur lihat sindrom di } \\
\text { atas. }\end{array}$ \\
\hline 12 & $\begin{array}{l}\text { 金嗓子喉片 } \\
\text { 翻译问题: 减译 } \\
\text { 源语: 疏风清热, 解毒利咽, 芳香辟秽。适用于改善急性咽炎, 急性喉炎所 } \\
\text { 致的咽喉肿痛, 干燥灼热, 声音嘶哑等症。 } \\
\text { 译语: Membantu meredakan panas yang disertai tenggorokan kering. } \\
\text { 建议翻译: Meredakan panas dalam dan masuk angin, detoksifikasi tenggorokan dan } \\
\text { mengatasi susah menelan. Cocok digunakan untuk mengatasi radang } \\
\text { tenggorokan akut, radang pita suara akut, tenggorokan kering dan panas, } \\
\text { suara serak dan lain lain. }\end{array}$ \\
\hline 13 & $\begin{array}{l}\text { 止血灵胶囊 } \\
\text { 翻译问题: 减译 } \\
\text { 源语: 清热, 解毒, 止血。用于子宫肌瘤出血, 恶露不净, 经间出血, 放环 } \\
\text { 出血, 痔疮出血, 鼻血等症。 } \\
\text { 译语: Membantu menghentikan pendarahan. } \\
\text { 建议翻译: Membantu mengatasi panas dalam, detoksifikasi tubuh, menghentikan } \\
\quad \text { pendarahan. Digunakan untuk menghentikan pendarahan akibat fibroid } \\
\text { rahim (tumor jinak pada otot rahim), menghentikan pendarahan } \\
\text { pascapersalinan, pendarahan pada saat tidak menstruasi, pendarahan } \\
\text { akibat wasir, mimisan dan lain-lain. }\end{array}$ \\
\hline 14 & $\begin{array}{l}\text { 步长宫瘤消胶囊 } \\
\text { 翻译问题: 减译 } \\
\text { 源语: 活血化瘀、软坚散结。用于子宫肌瘤属气滞血瘀证。证见: 月经量多, 夹 } \\
\quad \text { 有大小血块, 经期延长, 或有腹痛, 舌暗红, 或边有紫点、瘀斑, 脉细弦 } \\
\quad \text { 或细涩。 } \\
\text { 译语: Secara tradisional digunakan untuk membantu sirkulasi darah. } \\
\text { 建议翻译: Memperbaiki sirkulasi darah, mengatasi arterosklerosis (sumbatan pada }\end{array}$ \\
\hline
\end{tabular}




\begin{tabular}{|c|c|}
\hline & $\begin{array}{l}\text { saraf arteri oleh lemak, kolestrol dll.). Digunakan untuk mengatasi fibroid } \\
\text { rahim (tumor jinak pada otot rahim) yang disebabkan aliran darah dan } \\
\text { chi tidak lancar. Gejala : darah haid berlebihan dengan gumpalan darah } \\
\text { besar ataupun kecil, haid dengan jangka waktu yang panjang atau disertai } \\
\text { sakit perut, warna lidah berubah menjadi merah tua, ataupun di lidah } \\
\text { terdapat bintik ungu, ekimosis (ada memar atau biru pada kulit padahal } \\
\text { tidak terbentur). }\end{array}$ \\
\hline 15 & $\begin{array}{l}\text { 步长肝爽颗粒 } \\
\text { 翻译问题: 减译 } \\
\text { 源语: 疏肝健脾, 清热散瘀, 保肝护肝, 软坚散结。用于急、慢性肝炎, 肝 } \\
\text { 硬化, 肝功能损害。 } \\
\text { 译语: Secara tradisional digunakan untuk membantu memelihara kesehatan fungsi } \\
\text { hati. } \\
\text { 建议翻 译: Memperkuat dan menjaga fungsi limpa, mengatasi panas dalam dan } \\
\text { mengencerkan darah, mengatasi arterosklerosis (sumbatan pada saraf } \\
\text { arteri oleh lemak, kolestrol dll.). Digunakan untuk mengatasi radang liver } \\
\text { (hati) akut dan kronis, sirosis hati (kerusakan hati kronis dari berbagai } \\
\text { penyebab yang mengarah ke jaringan parut dan gagal hati) dan } \\
\text { penurunan fungsi hati. }\end{array}$ \\
\hline 16 & $\begin{array}{l}\text { 消渴丸 } \\
\text { 翻译问题: 减译 } \\
\text { 源语: 滋肾养阴, 益气生津。用于多饮, 多尿, 多食, 消瘦, 体倦无力, 眠差腰 } \\
\text { 痛, 尿糖及血糖升高之 “消渴症”。 } \\
\text { 译语: Secara tradisional digunakan untuk membantu meringankan gejala kencing } \\
\text { manis. } \\
\text { 建议翻译: Berguna untuk menjaga ginjal, memperbaiki aliran chi, menambah sekresi } \\
\text { air liur. Digunakan supaya banyak minum, banyak buang air kecil, } \\
\quad \text { banyak makan, menaikkan berat badan, mengatasi lemas dan lesu, } \\
\quad \text { kualitas tidur buruk, sakit pinggang, gula darah dan diabetes. }\end{array}$ \\
\hline 17 & $\begin{array}{l}\text { 健脑丸 } \\
\text { 翻译问题: 减译 } \\
\text { 源语: 补肾健脑, 养血安神。用于心肾亏虚所致的记忆减退、头晕目眩, 心悸失 } \\
\text { 眠、腰膝痠软; 老年轻度认知障碍见上述证候者。 } \\
\text { 译语: Membantu meringankan gejala gangguan sulit tidur. } \\
\text { 建 议翻 译: Mengoptimalkan fungsi gunjal, menjaga kesehatan otak, memelihara } \\
\quad \text { kelancaran aliran darah, menjaga pikiran agar tenang. Digunakan untuk } \\
\text { mengatasi masalah pikun yang disebabkan oleh gangguan jantung dan } \\
\text { ginjal, pusing, jantung berdebar, insomnia, sakit lutut dan pinggang, } \\
\quad \text { gangguan kognitif (fungsi memori otak) pada usia tua dan muda lihat }\end{array}$ \\
\hline
\end{tabular}




\begin{tabular}{|c|c|}
\hline & \\
\hline 18 & $\begin{array}{l}\text { 香菊胶囊 } \\
\text { 翻译问题: 减译 } \\
\text { 源语: 辛散祛风, 清热通窍。用于急、慢性鼻窦炎, 鼻炎。 } \\
\text { 译语: Membantu meredakan demam dan sinusitis. } \\
\text { 建议翻译: Mengatasi masuk angin, panas dalam. Digunakan untuk rhinitis (alergi } \\
\quad \text { yang menyebabkan pilek) dan sinusitis kronis serta akut. }\end{array}$ \\
\hline 19 & $\begin{array}{l}\text { 三金西瓜箱喉 } \\
\text { 翻译问题: 减译 } \\
\text { 源语: 清音利咽、消肿止痛。用于防治咽喉肿痛, 声音嘶哑, 喉痹, 喉痛, 喉蛾 } \\
\text { 口糜, 口舌生疮, 牙痛; 急、慢性咽喉炎, 扁桃体炎, 口腔炎, 牙齿肿痛。 } \\
\text { 译语: Membantu meredakan panas dalam yang disertai tenggorokan kering. } \\
\text { 建议翻译: Mengembalikan suara yang serak, mengurangi rasa sakit akibat radang } \\
\text { tenggorokan. Digunakan umtuk mencegah radang tenggorokan, suara } \\
\text { hilang/serak, tenggorokan berdahak atau infeksi bernanah, tenggorokan } \\
\text { perih, sariawan, sakit gigi, radang tenggorokan, dan radang amandel } \\
\text { kronis ataupun akut. }\end{array}$ \\
\hline 20 & $\begin{array}{l}\text { 三九感冒清热颗粒 } \\
\text { 翻译问题: 减译 } \\
\text { 源语: 疏风散寒, 解表清热。用于风寒感冒, 头痛发热, 恶寒身痛, 鼻流清流涕, } \\
\text { 咳嗽咽干。 } \\
\text { 译语: Membantu meredakan gejala salesma disertai tenggorokan kering. } \\
\text { 建议翻译: Mengatasi masuk angin dan mengigil, meredakan panas dalam. Digunakan } \\
\quad \text { untuk mengatasi flu (terutama karena masuk angin), sakit kepala, demam, } \\
\quad \text { menggigil dan tidak enak badan, hidung berair, batuk dan tenggorokan } \\
\quad \text { kering. }\end{array}$ \\
\hline 21 & $\begin{array}{l}\text { 田七痛经胶囊 } \\
\text { 翻译问题: 减译 } \\
\text { 源语: 通调气血, 止痛调经。用于经期腹痛及因寒所致的月经失调。 } \\
\text { 译 语: Secara tradisional membantu memperbaiki sirkulasi darah, membantu } \\
\text { meredakan nyeri dan membantu meringankan bengkak. } \\
\text { 建 议翻 译 : Secara tradisional digunakan untuk memperbaiki sirkulasi darah, } \\
\quad \text { meredakan sakit serta membantu memperlancar menstruasi. Digunakan } \\
\quad \text { untuk nyeri perut haid dan gangguan menstruasi yang disebabkan oleh } \\
\quad \text { cuaca dingin. }\end{array}$ \\
\hline 22 & $\begin{array}{l}\text { 复方阿胶浆 } \\
\text { 翻译问题: 误译 } \\
\text { 源语: 补气养血。用于头晕，失眠、心悸、贫血。 }\end{array}$ \\
\hline
\end{tabular}




\begin{tabular}{|c|c|}
\hline & $\begin{array}{l}\text { 译语: Membantu memelihara stamina. } \\
\text { 建议翻译: Membantu menambah trombosit darah, digunakan untuk kepala pusing, } \\
\text { sulit tidur, jantung berdebar kencang tidak beraturan dan anemia. }\end{array}$ \\
\hline 23 & $\begin{array}{l}\text { 鸡骨草丸 } \\
\text { 翻译问题: 误译 } \\
\text { 源语: 舒肝利胆, 清热解毒。用于急、慢性肝炎和胆囊炎属肝胆湿热症者。 } \\
\text { 译语: Secara tradisional digunakan untuk membantu sirkulasi darah. } \\
\text { 建议翻译: Berguna untuk fungsi lever dan empedu, mengurangi panas dalam dan } \\
\text { untuk detoksifikasi tubuh, digunakan untuk hepatitis dan kolesitisis } \\
\text { (radang lever dan radang empedu) akut dan kronis yang dikarenakan } \\
\text { panas dalam pada lever dan empedu. }\end{array}$ \\
\hline 24 & $\begin{array}{l}\text { 消乳散结胶囊 } \\
\text { 翻译问题: 误译 } \\
\text { 源语: 疏肝解郁, 化痰散结, 活血止痛。用于肝郁气滞, 痰瘀凝聚所致的乳腺增 } \\
\text { 生, 乳房胀痛。 } \\
\text { 译语: Membantu memelihara kesehatan. } \\
\text { 建议翻 译: Membantu melancarkan fungsi hati, mengurangi dan mengencerkan } \\
\text { dahak, melancarkan aliran darah chi dan meredakan rasa sakit. } \\
\text { Digunakan untuu hyperplasia payudara (keadaan dimana sel-sel dalam } \\
\text { payudara mengalami pertumbuhan yang tidak wajar dan mengembangkan } \\
\text { pola yang tidak biasa seperti normalnya terjadi pada payudara normal), } \\
\text { payudara nyeri atau bengkak. }\end{array}$ \\
\hline 25 & $\begin{array}{l}\text { 快胃片 } \\
\text { 翻译问题: 误译 } \\
\text { 源语: 制酸和胃, 收敛止痛。用于肝胃不和所致的胃脘疼痛、呕吐反酸、纳食减 } \\
\text { 少: 浅表性胃炎、胃及十二指肠溃病、胃窦炎见上述证候者。 } \\
\text { 译语: Membantu meringankan keluhan yang disebabkan gangguan pencernaan. } \\
\text { 建议翻译: Menurunkan gas asam lambung, dan meredakan sakit. Digunakan untuk } \\
\text { mengatasi kram perut, mual muntah akibat gas asam perut berlebih, nafsu } \\
\quad \text { makan berkurang, gastritis superfisial (peradangan dinding lambung), } \\
\quad \text { luka pada lambung dan usus } 12 \text { jari, gastritis antral (radang lambung di } \\
\text { bagian bawah perut *kasus ini lebih jarang ditemukan daripada gastritis } \\
\text { biasa) lihat sindrom di atas. }\end{array}$ \\
\hline 26 & $\begin{array}{l}\text { 保济丸 } \\
\text { 翻译问题: 误译 } \\
\text { 源语: 解表, 祛湿, 和中。用于暑湿感冒, 症见发热头痛、腹痛腹泻、恶心呕吐、 } \\
\quad \text { 肠胃不适; 亦可用于晕车晕船。 } \\
\text { 译语: Membantu memelihara kesehatan pencernaan. }\end{array}$ \\
\hline
\end{tabular}




\begin{tabular}{|c|c|}
\hline & $\begin{array}{l}\text { 建议翻译: Mengurangi kelembaban pada nafas ( yang menyebabkan kantuk dan } \\
\text { menurunkan kinerja tubuh). Digunakan untuk flu, gejala deman, sakit } \\
\text { kepala, nyeri perut dan diare, mual dan muntah, gangguan usus dan } \\
\text { maag, juga bisa digunakan untuk mabuk perjalanan dan mabuk laut. }\end{array}$ \\
\hline 27 & $\begin{array}{l}\text { 步长胆石利通片 } \\
\text { 翻译问题: 误译 } \\
\text { 源语: 理气解郁, 化病散结, 利胆排石。用于胆石病气滞型。症见: 右上腹胀满 } \\
\quad \text { 疼痛, 痛引肩背, 肯脘㾂病, 厌食油嵗。 } \\
\text { 译语: Membantu memelihara kesehatan fungsi hati. } \\
\text { 建议翻译: Mengatur chi dan melancarkan aliran darah, digunakan untuk meluruhkan } \\
\quad \text { batu empedu, gejala sakit pada perut kanan atas, sakit bahu dan } \\
\quad \text { punggung, tidak nafsu makan dan mual (terutama akibat makanan } \\
\quad \text { berminyak). }\end{array}$ \\
\hline 28 & $\begin{array}{l}\text { 步长乙肝清热解毒胶囊 } \\
\text { 翻译问题: 误译 } \\
\text { 源语 : 清肝利胆, 利湿解毒。用于肝胆湿热引起的黄㾝 (或无黄疸)、发烧 (或 } \\
\text { 低烧) 口干苦或粘臭, 厌油, 胃肠不适, 舌质红, 舌苔厚㖑, 脉弦滑数等; } \\
\text { 急慢性病毒性乙型肝炎初期或活动期; 乙型肝炎病毒携带者。见上述证候 } \\
\text { 者。 } \\
\text { 译语: Membantu memelihara kesehatan fungsi hati. } \\
\text { 建议翻译: Memelihara fungsi hati dan empedu, detoksifikasi tubuh dan mengurangi } \\
\text { lembab dalam nafas, digunakan untuk mengatasi menyakit kuning yang } \\
\text { disebabkan oleh kelembaban lever dan kantong empedu(atau yang tidak } \\
\text { disertai penyakit kuning), demam (atau demam rendah), mulut kering } \\
\text { pahit atau bau, kehilangan nafsu makan, mual (terutama akibat makan } \\
\text { makanan berminyak), gangguan maag dan usus, lidah memerah, lapisan } \\
\text { lidah tebal, Virus hepatitis B akut atau kronis stadium dini atau aktif, } \\
\text { pembawa virus hepatitis B, lihat sindrom di atas. }\end{array}$ \\
\hline 29 & $\begin{array}{l}\text { 三九胃泰颗粒 } \\
\text { 翻译问题: 误译 } \\
\text { 源语: 清热燥湿, 行气活血, 柔肝止痛。用于湿热内蕴、气滞血㾉所致的胃痛, } \\
\quad \text { 症见脘腹隐痛、饱胀反酸、恶心呕吐、嘈杂纳减; 浅表性胃炎见上述证候 } \\
\quad \text { 者。 } \\
\text { 译语: Membantu memelihara kesehatan fungsi pencernaan. } \\
\text { 建议翻译: Meredakan panas dalam dan nafas lembab (yang menyebabkan kantuk dan } \\
\quad \text { penurunan kinerja tubuh), melancarkan aliran darah chi, memelihara } \\
\quad \text { fungsi hati dan meredakan rasa sakit, digunakan untuk nyeri perut yang } \\
\quad \text { disebabkan oleh pendarahan dan gangguan aliran chi, gejala sakit perut, } \\
\quad \text { kembung akibat gas asam berlebihan dalam perut, mual, muntah, }\end{array}$ \\
\hline
\end{tabular}




\begin{tabular}{|c|c|}
\hline & tis (Radang lambung) lihat sindrom di atas. \\
\hline 30 & $\begin{array}{l}\text { 珍黄丸 } \\
\text { 翻译问题: 增译 } \\
\text { 源语: 清热解毒, 消肿止痛。用于咽喉肿痛, 疮疡热㽸。 } \\
\text { 译语: Membantu meringankan bisul, membantu meredakan gatal-gatal akibat gigitan } \\
\text { serangga. } \\
\text { 建议翻译: Meredakan panas dalam dan detoksifikasi tubuh, meredakan pembekakan } \\
\quad \text { dan rasa sakit, digunakan untuk tenggorokan bengkak, mengatasi bisul } \\
\quad \text { kulit dan furunkel (bisul karena tumbuhnya rambut di bawah jaringan } \\
\text { kulit). }\end{array}$ \\
\hline 31 & $\begin{array}{l}\text { 八珍丸 } \\
\text { 翻译问题: 增译 } \\
\text { 源语: 补气益血。用于气血两虚, 面色萎黄, 四肢乏力。 } \\
\text { 译语: Membantu meringankan gangguan sulit tidur dan memelihara kesehatan. } \\
\text { 建 议 翻 译: Memelihara kesehatan limpa dan maag, digunakan untuk mengatasi } \\
\quad \text { kekurangan darah dan chi, kulit pucat dan anggota tubuh lemas. }\end{array}$ \\
\hline 32 & $\begin{array}{l}\text { 补中益气丸 } \\
\text { 翻译问题: 增译 } \\
\text { 源语: 补中益气。用于体倦乏力, 内脏下垂。 } \\
\text { 译语: Membantu memelihara kesehatan limpa dan membantu memelihara kesehatan } \\
\quad \text { pencernaan. } \\
\text { 建议翻译: Memelihara kesehatan limpa dan maag, digunakan untuk mengatasi tubuh } \\
\quad \text { letih dan lesu, turun berok (hernia). }\end{array}$ \\
\hline
\end{tabular}

\section{Intra Aries 的药品建议翻译}

\begin{tabular}{|c|c|}
\hline 1 & $\begin{array}{l}\text { 腰痛片 } \\
\text { 翻译问题: 减译 } \\
\text { 源语: 强腰补肾, 活血止痛。用于肾虚腰痛, 腰肌劳损。 } \\
\text { 译语: Membantu memelihara kesehatan ginjal dan mengatasi sakit pinggang. } \\
\text { Membantu memperbaiki sirkulasi darah. } \\
\text { 建议翻译: Membantu memelihara kesehatan ginjal dan mengatasi sakit pinggang, } \\
\quad \text { menghentikan rasa sakit dan melancarkan peredaran darah. Digunakan } \\
\quad \text { untuk mengatasi masalah pada ginjal dan tegang pinggang. }\end{array}$ \\
\hline 2 & $\begin{array}{l}\text { 胃痛片 } \\
\text { 翻译问题：减译 } \\
\text { 源语：芳香行气，和中止痛。用于胃酸过多，胃痛及脘闪，呕吐等属气滞证 } \\
\quad \text { 者。 }\end{array}$ \\
\hline
\end{tabular}




\begin{tabular}{|c|c|}
\hline & $\begin{array}{l}\text { 译语: Membantu mengurangi sakit maag, menyembuhkan asam lambung yang } \\
\text { berlebihan, muntah-muntah dan rasa kembung. } \\
\text { 建议翻 译: Membantu menyelaraskan aliran chi dan meredakan rasa sakit. } \\
\text { Digunakan untuk menyembuhkan asam lambung yang berlebihan, } \\
\text { muntah-muntah dan rasa kembung. }\end{array}$ \\
\hline 3 & $\begin{array}{l}\text { 金菊五花茶颗粒 } \\
\text { 翻译问题: 减译 } \\
\text { 源语: 清热利湿, 凉血解毒, 清肝明目。用于大肠湿热所致的泄泻、痔血以 } \\
\text { 及肝热目赤, 风热咽痛, 口舌溃烂。 } \\
\text { 译语: Membantu meredakan panas dalam yang disertai tenggorokan kering, mata } \\
\text { merah dan sariawan. } \\
\text { 建 议翻 译 : Membantu meredakan panas, detoksifikasi darah, dan mempertajam } \\
\quad \text { penglihatan. Digunakan untuk diare yang disebabkan oleh usus besar } \\
\quad \text { yang lembab, penyumbatan darah, dan panas, sakit tenggorokan, serta } \\
\text { sariawan. }\end{array}$ \\
\hline 4 & $\begin{array}{l}\text { 鼻炎片 } \\
\text { 翻译问题: 减译 } \\
\text { 源语: 祛风宣肺, 清热解毒。用于急、慢性鼻炎风热蕴肺证, 症见鼻塞、流涕、 } \\
\quad \text { 发热、头痛。 } \\
\text { 译语: Membantu meredakan batuk berdahak, pilek, sakit kepala, dan infeksi pada } \\
\quad \text { hidung. } \\
\text { 建议翻译: Melawan reumatik dan meningkatkan fungsi paru-paru, panas dalam. } \\
\quad \text { Digunakan pada rhinitis (alergi karena debu, cuaca panas, cuaca dingin) } \\
\quad \text { akut dan kronis, gejala hidung tersumbat, pilek, demam, dan sakit kepala. }\end{array}$ \\
\hline 5 & $\begin{array}{l}\text { 伤湿止痛膏 } \\
\text { 翻译问题: 减译 } \\
\text { 源语: 风寒疼痛, 筋骨酸痛, 肩酸腰痛, 关节痛, 肌肉痛, 扭伤, 跌打损伤。 } \\
\text { 译语: Membantu meredakan keseleo, nyeri otot pinggang dan punggung. } \\
\text { 建议翻译: Membantu meredakan nyeri akibat angin, nyeri sendi dan tulang, nyeri } \\
\quad \text { pinggang dan bahu, nyeri otot, keseleo, dan memar. }\end{array}$ \\
\hline 6 & $\begin{array}{l}\text { 十全大补丸 } \\
\text { 翻译问题: 减译 } \\
\text { 源语: 温补气血。用于气血两虚, 面色苍白, 气短心悸, 头军自汗, 体倦乏力, } \\
\quad \text { 四肢不温, 月经量多。 } \\
\text { 译语: - - Membantu meredakan nyeri haid. } \\
\quad \text {-Mengatasi muka pucat pasi, pusing (keluar keringat dingin, nafas pendek dan } \\
\quad \text { jantung berdebar). } \\
\text { 建 议 翻 译: Membantu melancarkan aliran darah. Digunakan untuk mengatasi }\end{array}$ \\
\hline
\end{tabular}




\begin{tabular}{|c|c|}
\hline & $\begin{array}{l}\text { masalah peredaran darah, muka pucat pasi, pusing (keluar keringat } \\
\text { dingin, nafas pendek dan jantung berdebar), anggota badan tidak enak, } \\
\text { menstruasi dengan darah berlebih. }\end{array}$ \\
\hline 7 & $\begin{array}{l}\text { 海珠喘息定片 } \\
\text { 翻译问题: 减译 } \\
\text { 源语: 平喘、祛痰、镇静、止咳。用于支气管哮喘, 慢性气管炎。 } \\
\text { 译语: Membantu mengobati asma, sesak nafas, batuk dan nafas tersengal-sengal. } \\
\text { 建 议 翻 译： Melancarkan pernafasan, mengurangi dahak, menghentikan batuk, } \\
\quad \begin{array}{l}\text { digunakan untuk asthma, bronkitis kronis (infeksi pada saluran } \\
\text { pernapasan) }\end{array}\end{array}$ \\
\hline 8 & $\begin{array}{l}\text { 芪骨胶囊 } \\
\text { 翻译问题: 减译 } \\
\text { 源语: 滋养肝肾、强筋健骨。用于女性绝经后骨质疏松症肝肾不足证, 症见: 腰 } \\
\text { 膝酸软无力、腰背疼痛、步履艰难、不能持重。 } \\
\text { 译语: Membantu memelihara kesehatan wanita, liver, ginjal, menguatkan otot dan } \\
\quad \text { tulang. Untuk wanita menopause membantu mencegah osteoporosis, pegal } \\
\quad \text { linu, dan sakit pinggang. } \\
\text { 建议翻译: Membantu memelihara kesehatan liver dan ginjal, menguatkan otot dan } \\
\quad \text { tulang, membantu mencegah osteoporosis, masalah hati dan ginjal pasca } \\
\text { menopause pada wanita. Gejala: sakit pinggang, lutut sakit dan lemah, } \\
\text { sulit berjalan, tidak bisa fokus. }\end{array}$ \\
\hline 9 & $\begin{array}{l}\text { 壮腰健肾丸 } \\
\text { 翻译问题: 减译 } \\
\text { 源语: 壮腰健肾, 养血, 祛风湿。用于肾亏腰痛, 膝软无力, 小便频数, 风湿骨 } \\
\text { 痛, 神经衰弱。 } \\
\text { 译语: Membantu meredakan pegal linu, sakit otot pinggang, membantu melancarkan } \\
\text { buang air seni dan peredaran darah serta memperkuat kinerja ginjal. } \\
\text { 建 议 翻 译 : Membantu meredakan pegal linu, sakit otot pinggang, membantu } \\
\quad \text { melancarkan buang air seni dan peredaran darah serta memperkuat } \\
\quad \text { kinerja ginjal, meredakan reumatik, dan gangguan saraf. }\end{array}$ \\
\hline 10 & $\begin{array}{l}\text { 安宫牛黄丸 } \\
\text { 翻译问题: 减译 } \\
\text { 源语: 该药品具有清热解毒、镇惊开䛎等功效。可用于热病、邪入心包、高热惊 } \\
\text { 厥、神昏谵语; 中风昏迷及脑炎、脑膜炎、中毒性脑病、脑出血、败血症 } \\
\text { 见上述证候者。 } \\
\text { 译语: Untuk membantu meredakan demam, kejang panas tinggi, stroke, meredakan } \\
\quad \text { gejala gangguan sulit tidur dan merangsang kesadaran yang hilang yang } \\
\text { disebabkan oleh panas tinggi. } \\
\text { 建议翻译: Untuk membantu meredakan demam dan detoksifikasi tubuh, panas tinggi, }\end{array}$ \\
\hline
\end{tabular}




\begin{tabular}{|c|c|}
\hline & $\begin{array}{l}\text { stroke, menjaga kesehatan jantung, pendarahan otak, radang otak, radang } \\
\text { selaput otak, meredakan gejala gangguan sulit tidur dan merangsang } \\
\text { kesadaran yang hilang yang disebabkan oleh panas tinggi. }\end{array}$ \\
\hline 11 & $\begin{array}{l}\text { 连花清瘟胶囊 } \\
\text { 翻译问题: 减译 } \\
\text { 源语: 清瘟解毒, 宣肺泄热。用于治疗流行性感冒属热毒袭肺证, 症见: 发 } \\
\text { 热或高热, 恶寒, 肌肉酸痛, 鼻塞流涕, 咳嗽, 头痛, 咽干咽痛, 舌 } \\
\text { 偏红, 苔黄或黄淢等。 } \\
\text { 译语: Membantu meredakan panas dalam, flu, demam, pegal linu, sakit kepala yang } \\
\text { disertai tenggorokan kering dan meredakan batuk. } \\
\text { 建议翻译: Membantu meredakan panas dalam dan detoksifikasi tubuh, digunakan } \\
\quad \text { untuk pengobatan influenza dengan gejala : demam tinggi, menggigil, } \\
\quad \text { sakit otot, hidung tersumbat, batuk, sakit kepala, sakit tenggorokan, lidah } \\
\text { memerah, atau berlendir. }\end{array}$ \\
\hline 12 & $\begin{array}{l}\text { 血塞通滴丸 } \\
\text { 翻译问题: 减译 } \\
\text { 源语: 活血化瘀, 通脉活络。具有抑制血小板聚集和增加脑血流量的作用。用于 } \\
\quad \text { 脑路瘀阻, 胸痹心痛; 脑血管后遗症、冠心病心绞痛属上述证候者。 } \\
\text { 译 语 : Membantu memelihara kesehatan, melancarkan peredaran darah, dan } \\
\text { mencegah penyumbatan pembuluh darah di otak. } \\
\text { 建议翻译: Melancarkan peredaran darah, dan mencegah penyumbatan pembuluh } \\
\quad \text { darah di otak, nyeri dada, nyeri jantung, sindrom di atas adalah gejala } \\
\text { dari penyakit jantung coroner dan angina petcoris. }\end{array}$ \\
\hline 13 & $\begin{array}{l}\text { 中国吉林野生灵芝 } \\
\text { 翻译问题: 减译 } \\
\text { 源语: -苦平无毒, 主治胸中结。益心气, 补中增智慧, 不忘, 久食轻身不老。 } \\
\quad \text { 延年神仙。 } \\
\text {-甘温无毒。主治耳狵, 利关节, 保神、益精气, 坚筋骨, 好颜色。久服 } \\
\quad \text { 轻身。不老延年。 } \\
\text { 译语: Sebagai makanan suplemen untuk pria dan wanita, memperkuat badan, awet } \\
\quad \text { muda serta bertenaga, mempertinggi fitalitas dan kesehatan. } \\
\text { 建议翻译: Untuk memperbaiki pendengaran, baik untuk sendi saraf dan tulang, untuk } \\
\quad \text { konsentrasi, memperbaiki aliran chi, anti-aging, mempertinggi fitalitas } \\
\quad \text { dan kesehatan. }\end{array}$ \\
\hline 14 & $\begin{array}{l}\text { 赛胃安胶囊 } \\
\text { 翻译问题: 减译 } \\
\text { 源语: 止血, 消炎, 收敛, 促进肉芽新生, 使溃疡面愈合。用于胃、十二指 } \\
\quad \text { 肠溃疡, 急、慢性胃炎, 食道炎, 口腔炎。 }\end{array}$ \\
\hline
\end{tabular}




\begin{tabular}{|c|c|}
\hline & $\begin{array}{l}\text { 译语: Menyembuhkan infeksi dan pendarahan pada lambung, mengobati infeksi pada } \\
\text { tenggorokan,mengobati gaangguan pada lambung dan rongga mulut. } \\
\text { 建议翻 译: Menghentikan pendarahan, anti peradangan, mulut kering. Digunakan } \\
\text { untuk lambung, usus } 12 \text { jari, gastritis (radang dinding lambung) akut dan } \\
\text { kronis, tukak lambung, sariawan. }\end{array}$ \\
\hline 15 & $\begin{array}{l}\text { 安神补脑片 } \\
\text { 翻译问题: 减译 } \\
\text { 源语: 补肝益肾, 宁心安神。用于头痛头昏、怔悸失眠、遗精多梦、肝肾不足。 } \\
\text { 译语: Membantu meredakan sakit kepala dan meringankan gangguan sulit tidur. } \\
\text { 建 议翻译: Memperbaiki fungsi hati dan ginjal, menenangkan syaraf. Digunakan } \\
\quad \text { untuk sakit kepala dan pusing, mengatasi insomnia, masalah hati dan } \\
\quad \text { ginjal. }\end{array}$ \\
\hline 16 & $\begin{array}{l}\text { 复方西羚解毒胶囊 } \\
\text { 翻译问题: 减译 } \\
\text { 源语: 疏风解表, 清热解毒。用于外感风热, 发热、头痛, 咳嗽音哑, 咽喉肿痛。 } \\
\text { 译语: Membantu meredakan panas dalam yang disertai sakit tenggorokan kering dan } \\
\text { membantu meredakan batuk. } \\
\text { 建议翻译: Meredakan panas dalam dan detoks tubuh. Digunakan untuk meredakan } \\
\quad \text { penyakit yang disebabkan akibat udara panas, panas dalam, sakit kepala, } \\
\text { batuk dan suara serak, radang tenggorokan. }\end{array}$ \\
\hline 17 & $\begin{array}{l}\text { 正宗泰和乌鸡白凤丸 } \\
\text { 翻译问题: 减译 } \\
\text { 源语: 补气养血, 调经止带。用于: 气血两虚, 身体瘦弱, 腰膝酸软, 月经不调, } \\
\text { 崩漏带下。又用于妇女经期腹痛, 肢体浮肿, 产后体弱, 虚汗低热等。 } \\
\text { 译语: Memelihara kesehatan. Membantu memperlancar peredaran darah. Membantu } \\
\text { menyembuhkan pusing dan keputihan. } \\
\text { 建 议翻 译 : Memelihara kesehatan darah, memperlancar menstruasi dan } \\
\text { menghentikan keputihan. Digunakan untuk mengatasi masalah aliran } \\
\text { darah, tubuh kurus dan lemas, lutut pinggang lemas dan nyeri, haid tidak } \\
\text { teratur, perdarahan pada saluran kencing dan keputihan. Juga digunakan } \\
\text { untuk mengurangi nyeri perut saat haid, anggota tubuh bengkak, lemas } \\
\text { pasca persalinan, keringat yang tidak wajar, demam ringan dll. }\end{array}$ \\
\hline 18 & $\begin{array}{l}\text { 新癀片 } \\
\text { 翻译问题: 误译 } \\
\text { 源语: 清热解毒, 活血化瘀, 消肿止痛。用于热毒瘀血所致的咽喉肿痛、牙痛、 } \\
\quad \text { 痹痛、胁痛、黄㾝、无名肿毒等症。 } \\
\text { 译语: Membantu memelihara kesehatan fungsi hati. } \\
\text { 建议翻译: Meredakan panas dalam dan detoksifikasi tubuh, melancarkan sirkulasi }\end{array}$ \\
\hline
\end{tabular}




\begin{tabular}{|c|c|}
\hline & $\begin{array}{l}\text { darah, meredakan pembengkakan dan rasa sakitnya, digunakan untuk } \\
\text { sakit tenggorokan, sakit gigi, kram, penyakit berat, penyakit kuning, dan } \\
\text { penyakit berat lainnya. }\end{array}$ \\
\hline 19 & $\begin{array}{l}\text { 暗疮丸 } \\
\text { 翻译问题: 误译 } \\
\text { 源语: 清热解毒、清热祛湿、清肝明目、消炎杀菌、抗敏, 平行面部油脂, 长期 } \\
\text { 使用会使皮肤洁白细淢、滑爽柔和, 保持着容光焕发的健康形象。 } \\
\text { 源语: Membantu mengurangi gatal-gatal, bisul, korengan, dan jerawat. } \\
\text { 建 议翻 译 : Meredakan panas dalam dan detoksifikasi tubuh, menghilangkan } \\
\text { kelembaban pada nafas yang menyebabkan kantuk dan penurunan kinerja } \\
\text { tubuh, membersihkan liver, memperbaiki pengelihatan, anti inflammasi, } \\
\text { anti alergi, menyeimbangkan produksi minyak wajah, penggunaan jangka } \\
\text { panjang mampu membuat kulit putih, halus, lembut dan mempertahankan } \\
\text { citra wajah sehat dan bercahaya. }\end{array}$ \\
\hline 20 & $\begin{array}{l}\text { 珠明眼丸 } \\
\text { 翻译问题: 误译 } \\
\text { 源语: 清热散风, 滋肝补肾, 益精血, 明目止痛。 } \\
\text { 译语 : Membantu memelihara kesehatan mata, menerangkan penglihatan, dan } \\
\text { menghilangkan rasa sakit pada mata. } \\
\text { 建议翻译: Meredakan panas dalam dan masuk angin, memperbaiki fungsi hati dan } \\
\quad \text { ginjal, melancarkan aliran darah, menerangkan pengelihatan dan } \\
\text { menghilangkan rasa sakit pada mata. }\end{array}$ \\
\hline 21 & $\begin{array}{l}\text { 赛霉安散 } \\
\text { 翻译问题: 增译 } \\
\text { 源语: 清热止血, 收敛祛湿, 化腐生肌。 } \\
\text { 译语: Membantu mengurangi luka ringan, biang keringat dan gatal - gatal. } \\
\text { 建议翻译: Membantu meredakan demam dan menghentikan pendarahan, mengobati } \\
\quad \text { iritasi, dan mengurangi gatal-gatal. }\end{array}$ \\
\hline 22 & $\begin{array}{l}\text { 山东阿胶浆 } \\
\text { 翻译问题: 增译 } \\
\text { 源语: 补气养血。用于气血两虚, 头晕目眩, 心悸失眠, 食欲不振及贫血。 } \\
\text { 译语: -Membantu memelihara kesehatan badan } \\
\text {-Membantu mengatasi gangguan siklus haid } \\
\text {-Meningkatkan jumlah trombosit pada pasien demam berdarah } \\
\text {-Meningkatkan daya tahan tubuh } \\
\text {-Meningkatkan sel darah putih pada pasien kanker yang menjalani kemoterapi } \\
\text { dan radiasi } \\
\text {-Membantu menambah darah dan energi pada anemia dengan gejala pusing, } \\
\text { berkunang-kunang, lemah tidak bertenaga dan sulit tidur. }\end{array}$ \\
\hline
\end{tabular}




\begin{tabular}{|c|c|}
\hline & $\begin{array}{l}\text { 议翻译: Memelihara aliran darah, digunakan untuk mengatasi pusing, gangguan } \\
\text { mata, jantung berdebar dan insomnia, kehilangan nafsu makan dan } \\
\text { anemia. }\end{array}$ \\
\hline 23 & $\begin{array}{l}\text { 大活络丹 } \\
\text { 翻译问题: 增译 } \\
\text { 源语: 社风舒筋, 活络, 除湿。 } \\
\text { 译语: Secara tradisional digunakan untuk membantu meredakan pegal linu dan nyeri } \\
\quad \text { otot, rematik, rasa sakit pada leher dan tulang belakang, otot kaku dan sulit } \\
\quad \text { bergerak. } \\
\text { 建议翻译: Mengatasi masuk angin dan menenangkan saraf, mengaktifkan aliran chi, } \\
\quad \text { dan mengurangi lembab dalam nafas yang menyebabkan kantuk. }\end{array}$ \\
\hline 24 & $\begin{array}{l}\text { 至宝三鞭精 } \\
\text { 翻译问题: 增译 } \\
\text { 源语: 补血生精, 健脑补肾。 } \\
\text { 译语: Membantu memelihara stamina, menguatkan ginjal, memperlancar peredaran } \\
\quad \text { darah, mengobati jantung lemah dan saraf. } \\
\text { 建议翻译: Memelihara kesehatan aliran darah, otak dan ginjal. }\end{array}$ \\
\hline 25 & $\begin{array}{l}\text { 黄连素片 } \\
\text { 翻译问题: 增译 } \\
\text { 源语: 清热燥湿, 行气止痛, 止痢止泻。用于大肠湿热, 赤白下痢, 里急后重或 } \\
\text { 暴注下泻, 肛门灼热; 肠炎、痢疾见上述证候者。 } \\
\text { 译 语: Membantu mengurangi frekuensi buang air besar dan memadatkan tinja, } \\
\text { menyembuhkan sakit perut akibat bakteri. } \\
\text { 建 议翻 译: Mengurangi panas dalam, mengeringkan nafas lembab, melancarkan } \\
\text { aliran chi dan sebagai pereda nyeri, meredakan diare dan disentri, } \\
\text { digunakan untuk mengatasi masalah usus besar, radang usus, dubur } \\
\text { terbakar, membantu mengurangi frekuensi buang air besar dan } \\
\text { memadatkan tinja, menyembuhkan sakit perut akibat bakteri. }\end{array}$ \\
\hline 26 & $\begin{array}{l}\text { 海山驱风油 } \\
\text { 翻译问题: 增译 } \\
\text { 源语: 能深入疼痛患处, 迅速消除各种肌肉疼痛, 扭伤, 疙伤, 背痛, 关节痛等。 } \\
\text { 译语: Membantu meredekan nyeri otot dan nyeri sendi,sakit otot punggung, memar, } \\
\text { sakit perut, sakit kepala, pusing, flu, diare, digigit serangga dan lain-lain. } \\
\text { 建议翻译: Membantu meredakan penyakit dalam, mempercepat penyembuhan sakit } \\
\quad \text { karena keseleo, memar, sakit punggung, nyeri sendi dan lain lain. }\end{array}$ \\
\hline 27 & $\begin{array}{l}\text { 六味地黄丸 } \\
\text { 翻译问题: 增译 } \\
\text { 源语: 滋阴补肾。用于肾阴亏损, 头晕耳鸣, 腰膝酸软, 骨蒸潮热, 盗汗遗精。 }\end{array}$ \\
\hline
\end{tabular}




\begin{tabular}{|c|c|}
\hline & $\begin{array}{l}\text { 译语: Membantu memelihara kesehatan fungsi ginjal dan melancarkan buang air } \\
\text { kecil. } \\
\text { 建议翻译: Menambah cairan tubuh dan darah. Digunakan untuk mengatasi masalah } \\
\text { gangguan ginjal, pusing, telinga berdengung, pinggang dan lutut sakit } \\
\text { dan lemas. }\end{array}$ \\
\hline 28 & $\begin{array}{l}\text { 鼻敏感丸 } \\
\text { 翻译问题: 增译 } \\
\text { 源语: 急慢性鼻炎, 过敏性鼻炎, 花粉症, 鼻塞流涕。 } \\
\text { 译语: Membantu melegakan pernafasan dan meredakan batuk berdahak, infeksi pada } \\
\quad \text { hidung, alergi pada saluran pernafasan, penyumbatan saluran pernafasan, } \\
\text { asma dan bronchitis. } \\
\text { 建议翻 译: Melegakan pernafasan yang tersumbat akibat berbagai macam alergi, } \\
\text { meredakan pilek dan hidung tersumbat. }\end{array}$ \\
\hline 29 & $\begin{array}{l}\text { 石淋通 } \\
\text { 翻译问题: 误译 } \\
\text { 源语: 泌尿系结石。 } \\
\text { 译语: Membantu melancarkan buang air seni dan meluruhkan batu urin. } \\
\text { 建议翻译: Meluruhkan batu saluran kandung kemih (batu ginjal). }\end{array}$ \\
\hline 30 & $\begin{array}{l}\text { 清感穿心莲胶囊 } \\
\text { 翻译问题: 增译 } \\
\text { 源语: 传统上, 用于清热解毒, 消炎退肿, 扁桃腺炎, 咽喉肿痛及化痰止咳。 } \\
\text { 译 语: Membantu meredakan batuk, sakit tenggorokan, demam, mengobati infeksi } \\
\text { pada lambung, infeksi saluran kencing dan ginjal. } \\
\text { 建 议 翻 译 : Secara tradisional berguna meredakan panas dalam, detox tubuh, } \\
\quad \text { meredakan pembengkakan dan radang amandel, mengobati radang/sakit } \\
\quad \text { tenggorokan, serta meredakan batuk. }\end{array}$ \\
\hline 31 & $\begin{array}{l}\text { 通心络胶囊 } \\
\text { 翻译问题: 减译 } \\
\text { 源语: 益气活血, 通络止痛。用于冠心病心绞痛属心气虚乏、血瘀络阻证, 症见 } \\
\text { 胸部憋闷, 刺痛、绞痛, 固定不移, 心悸自汗, 气短乏力, 舌质紫暗或有 } \\
\text { 瘀斑, 脉细涩或结代。亦用于气虚血瘀络阻型中风病, 症见半身不遂或偏 } \\
\text { 身麻木, 口舌丕斜, 言语不利。 } \\
\text { 译语: Secara tradisional digunakan untuk membantu sirkulasi darah dan menambah } \\
\text { energi. Bagi penderita jantung koroner dapat meredakan rasa sakit, jantung } \\
\text { berdebar, sesak nafas, rasa nyeri pada dada dan melancarkan penyumbatan } \\
\text { pada penderita stroke (mulut miring/bicara tidak jelas/lidah kaku). } \\
\text { 建议翻译: Membantu melancarkan sirkulasi darah, mengurangi rasa sakit dengan } \\
\text { mengurangi sumbatan pada jaringan meridian (saluran aliran chi), } \\
\text { memperbaiki mood bagi penderita jantung coroner serta angina pectoris, }\end{array}$ \\
\hline
\end{tabular}




\begin{tabular}{|c|c|}
\hline & $\begin{array}{l}\text { menghentikan pendarahan, sesak nafas, rasa tersengat dan terbakar, } \\
\text { kram,keringat dingin, jantung berdebar, juga digunakan untuk penyakit } \\
\text { seperti stroke atau mati rasa separuh badan bibir dan lidah miring, } \\
\text { gangguan bicara. }\end{array}$ \\
\hline 32 & $\begin{array}{l}\text { 海山华陀跌打止痛膏 } \\
\text { 翻译问题: 误译 } \\
\text { 源语: 跌打扭伤, 肌肉酸痛, 腰酸背痛。 } \\
\text { 译语: Membantu meredakan nyeri otot dan nyeri sendi, rasa kaku pada leher dan } \\
\quad \text { bahu, keseleo dan memar. } \\
\text { 建议翻译: Membantu meredakan nyeri akibat terkilir, nyeri dan sakit pada otot, serta } \\
\quad \text { nyeri dan sakit pada pinggang dan punggung. }\end{array}$ \\
\hline 33 & $\begin{array}{l}\text { 月见草 } \\
\text { 翻译问题: 增译 } \\
\text { 源语: 防止高血压、动脉硬化, 冠心病、外周血管疾病, 高脂血症、降胆固醇。 } \\
\text { 译语: Mencegah dan meobati Arterial Sclerosis, Coronary heart Disease, Diabetes } \\
\text { Melitus, Obesity Atopic Eczema, Premenstrual Syndrome, Schizophrenia, } \\
\text { Alcohol intoxication dan penundaan usia tua. } \\
\text { 建议翻译: Mencegah darah tinggi, mengobati arterial sclerosis (penebalan dinding } \\
\text { pembuluh darah yg menyebabkan stroke), jantung koroner, gangguan } \\
\text { peredararan darah tepi, hyperlipidemia (ketidakseimbangan lemak darah), } \\
\text { mengurangi kolesterol. }\end{array}$ \\
\hline 34 & $\begin{array}{l}\text { 增肥丸 } \\
\text { 翻译问题: 增译 } \\
\text { 源语: 补健强身、消化不良、夜睡不宁、病后失调、先天不足、面黄肌瘦、血气 } \\
\text { 两亏、久廭不愈、疲倦无神、食欲不振。 } \\
\text { 译语: -Membantu memelihara kesehatan pencernaan dan membantu memperbaiki } \\
\text { nafsu makan } \\
\text {-Memperkuat daya tahan tubuh, memperlancar peredaran darah, memperkuat } \\
\text { lambung dan usus agar tetap sehat, meningkatkan kemampuan tubuh secara } \\
\text { maksimal untuk penyerapan nutrisi dan vitamin dari makanan. } \\
\text {-Membantu tubuh dalam meregenerasi sel-sel darah, mengobati insomnia } \\
\text { (sulit tidur) dan menyembuhkan migrain akibat kurang tidur. } \\
\text { 建 议 翻 译 : Membantu memelihara kesehatan dan memperkuat fisik,gangguan } \\
\text { pencernaan dan maag, memperbaiki kualitas tidur, mengurangi gangguan } \\
\text { pasca-sakit, cacat bawaan, meningkatkan nutrisi pada tubuh, mengatasi } \\
\text { kekurangan darah, mengatasi batuk berkepanjangan, lelah dan tidak } \\
\text { fokus, kehilangan nafsu makan. }\end{array}$ \\
\hline 35 & $\begin{array}{l}\text { 汉苑良方 百消丸 } \\
\text { 翻译问题: 误译 }\end{array}$ \\
\hline
\end{tabular}




\begin{tabular}{|c|c|}
\hline & $\begin{array}{l}\text { 源语: 具有祛黄褐斑的保健功能。 } \\
\text { 译语: Membantu memelihara kesehatan. } \\
\text { 建议翻译: Memiliki kemampuan perawatan kesehatan dengan mengurangi melasma } \\
\quad \text { (bercak berwarna cokelat hingga abu-cokelat pada wajah,lengan, leher } \\
\quad \text { atau bagian kulit lainnya). }\end{array}$ \\
\hline 36 & $\begin{array}{l}\text { 追风透骨丸 } \\
\text { 翻译问题: 减译 } \\
\text { 源语功能: 调和气血、强筋健骨、舒筋活络、驱风镇痛。 } \\
\text { 源语主治: 腰腿庱痛、四肢麻木、步履艰难、肌肉劳损: 一切因风通痹等症、疗 } \\
\text { 效显著。 } \\
\text { 译语: Digunakan untuk perawatan matirasa bagi penderita baru maupun lama yang } \\
\text { disebabkan oleh angin, udara dingin maupun lembab, seperti rematik, mati } \\
\text { rasa dibagian kaki dan tangan, susah berjalan, mengurangi rasa sakit karena } \\
\text { rematik dan sakit pinggang. } \\
\text { 建 议翻 译 : Menyeimbangkan darah, memperkuat otot dan tulang, melancarkan } \\
\text { peredaran darah dan meridien (aliran chi), meredakan reumatik dan } \\
\text { Pebagai obat analgesik } \\
\text { otot : semua rasa sakit yang disebabkan karena angin dan lain lain, efek } \\
\text { penyembuhannya signifikan }\end{array}$ \\
\hline 37 & $\begin{array}{l}\text { 活络油 } \\
\text { 翻译问题: 减译 } \\
\text { 源语: 跌打肿痛, 腰酸背痛, 筋络抽缩, 舒筋活络。 } \\
\text { 译 语: Membantu meredakan encok, pegal linu, masuk angin dan memperbaiki } \\
\quad \text { sirkulasi darah. } \\
\text { 建 议 翻 译 : Meredakan sakit karena bengkak, nyeri pinggang dan punggung, } \\
\quad \text { meredakan kram dan merilekskan saraf. }\end{array}$ \\
\hline
\end{tabular}

\section{Perdana Sakti 的药品建议翻译}

\begin{tabular}{|c|c|}
\hline 1 & $\begin{array}{l}\text { 六神丸 } \\
\text { 翻译问题: 减译 } \\
\text { 源语: 清凉解毒, 清炎止痛。用于烂喉丹痧, 咽喉肿痛, 喉风喉痛, 单双乳蛾, } \\
\text { 小儿热疤, 痛疡疔疮, 乳痛发背, 无名肿毒。 } \\
\text { 译语: Membantu meredakan sakit tenggorokan dan sariawan. } \\
\text { 建议翻译: Membantu meredakan demam, peradangan dan sakit. Digunakan untuk } \\
\quad \text { orang yang sakit dan radang tenggorokan, amandel, radang kulit, } \\
\quad \text { benjolan pada payudara, dan pembengkakan lainnya. }\end{array}$ \\
\hline 2 & 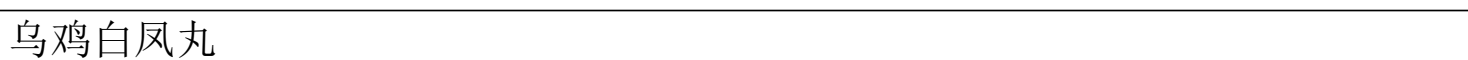 \\
\hline
\end{tabular}




\begin{tabular}{|c|c|}
\hline & $\begin{array}{l}\text { 翻译问题: 减译 } \\
\text { 源语: 补气养血, 调经止带。用于气血两虚, 身体瘦弱, 腰膝酸软, 月经不 } \\
\text { 调, 带下。 } \\
\text { 译语: Secara tradisional digunakan untuk membantu sirkulasi darah. } \\
\text { 建 议 翻 译 : Secara tradisional digunakan untuk membantu sirkulasi darah, } \\
\quad \text { melancarkan siklus menstruasi dan mengatasi keputiham. Digunakan } \\
\quad \text { untuk peredaran darah tidak lancar, badan yang kurus dan lemah, } \\
\quad \text { pinggang dan lutut yang pegal, mentruasi tidak lancar, serta keputihan. }\end{array}$ \\
\hline 3 & $\begin{array}{l}\text { 牛黄解毒片 } \\
\text { 翻译问题: 减译 } \\
\text { 源语: 清热解毒, 用于火热内盛, 咽喉肿痛, 牙龈肿痛, 口舌生疮, 目赤肿 } \\
\text { 痛。 } \\
\text { 译语: Membantu meredakan sakit tenggorokan dan panas dalam. } \\
\text { 建议翻译: Membantu meredakan demam, digunakan untuk mengobati panas dalam, } \\
\quad \text { sakit tenggorokan, sakit gigi, sariawan, mata merah dan bengkak. }\end{array}$ \\
\hline 4 & $\begin{array}{l}\text { 清肺抑火片 } \\
\text { 翻译问题: 减译 } \\
\text { 源语: 清肺止嗽, 降火生津。用于肺热咳嗽, 痰延雍盛, 咽喉肿痛, 牙齿疼痛, } \\
\text { 大便干燥。 } \\
\text { 译语: Membantu meredakan batuk yang disertai sesak nafas dan sakit tenggorokan. } \\
\text { 建 议翻 译: Membersihkan paru paru dan menghentikan batuk, meredakan panas } \\
\text { dalam dan menambah cairan tubuh. Digunakan untuk mengatasi batuk, } \\
\text { panas dalam di bagian paru-paru, mulut kering, radang tenggorokan, } \\
\text { sakit gigi, dan gangguan pencernaan. }\end{array}$ \\
\hline 5 & $\begin{array}{l}\text { 养阴清肺糖浆 } \\
\text { 翻译问题: 减译 } \\
\text { 源语: 养阴润肺, 清热利咽。用于咽喉干燥疼痛, 干咳、少痰或无痰。 } \\
\text { 译 语 : Membantu mengobati batuk, memperlancar pengeluaran dahak, sakit } \\
\text { tenggorokan dan gatal-gatal pada saluran pernafasan. } \\
\text { 建议翻译: Memperlancar pernafasan, meredakan panas dalam dan mengatasi rasa } \\
\quad \text { sulit menelan. Digunakan untuk mengatasi tenggorokan kering, batuk } \\
\quad \text { dengan sedikit dahak atau batuk kering. }\end{array}$ \\
\hline 6 & $\begin{array}{l}\text { 黄连上清片 } \\
\text { 翻译问题: 减译 } \\
\text { 源语: 清炎, 解热, 清火, 散风。散风清热, 泻火止痛。用于头昏耳鸣, 牙根肿 } \\
\quad \text { 痛, 口舌生疮, 咽喉红肿, 暴发火眼, 大便燥结, 小便赤黄。 } \\
\text { 译语: Membantu meredakan panas dalam yang disertai tenggorokan kering. } \\
\text { 建议翻译: Meredakan radang, panas dalam, dan masuk angin, menghilangkan rasa }\end{array}$ \\
\hline
\end{tabular}




\begin{tabular}{|c|c|}
\hline & $\begin{array}{l}\text { sakit dan mengatasi gejala-gejala gangguan tubuh akibat panas dalam } \\
\text { berlebihan. Digunakan untuk mengatasi pusing, telinga berdengung, gusi } \\
\text { bengkak, sariawan, radang tenggorokan, mata merah, tinja kering dan } \\
\text { urine berwarna oranye. }\end{array}$ \\
\hline 7 & $\begin{array}{l}\text { 连尧败毒片 } \\
\text { 翻译问题: 减译 } \\
\text { 源语: 清热解毒, 消肿止痛。用于灼热发烧, 流脓流水。 } \\
\text { 译语: Membantu meredakan demam. } \\
\text { 建议翻译: Membantu meredakan demam, menghilangkan bengkak dan meredakan } \\
\quad \text { sakit. Digunakan untuk orang yang demam dam cacar air. }\end{array}$ \\
\hline 8 & $\begin{array}{l}\text { 霍香气正水 } \\
\text { 翻译问题: 减译 } \\
\text { 源语: 扶正气、去暑邪、理肠胃、止吐泻。用于暑天受寒, 发烧伤食, 胃肠不适, } \\
\text { 气闷胸满, 头痛腹疼。 } \\
\text { 译语: Membantu meredakan sakit kepala dan gangguan pencernaan seperti mual, } \\
\text { muntah dan perut kembung. } \\
\text { 建 议翻 译: Membantu menaikkan imun tubuh, mengurangi gangguan-gangguan } \\
\quad \text { kesehatan akibat cuaca panas, memperbaiki fungsi usus dan lambung } \\
\quad \text { serta meredakan muntah dan diare, juga digunakan untuk mengatasi flu, } \\
\quad \text { demam, kehilangan nafsu makan, sesak nafas, sakit kepala, dan gangguan } \\
\text { perncernaan. }\end{array}$ \\
\hline 9 & $\begin{array}{l}\text { 香砂养胃片 } \\
\text { 翻译问题: 减译 } \\
\text { 源语: 健胃消食, 舒气止痛。用于胃肠衰弱, 消化不良, 胸膈膨闪, 腹痛, 呕吐, } \\
\text { 肠鸣, 泻泄。 } \\
\text { 译语: Membantu mengatasi gangguan pencernaan seperti mual, kembung dan nyeri } \\
\text { lambung. } \\
\text { 建议翻译: Memelihara fungsi lambung, melancarkan aliran chi dan meredakan rasa } \\
\quad \text { sakit. Digunakan untuk mengatasi gangguan saluran pencernaan, } \\
\text { pencernaan tidak lancar, dada bengkak, muntah-muntah, dan diare. }\end{array}$ \\
\hline 10 & $\begin{array}{l}\text { 银尧解毒片 } \\
\text { 翻译问题: 减译 } \\
\text { 源语: 清热散风, 解表退烧, 用于流行性感冒, 发冷发烧, 四肢酸懒, 头疼咳嗽, } \\
\text { 咽喉肿痛。 } \\
\text { 译语: Membantu meredakan sakit kepala, batuk, rasa sakit pada tenggorokan, dan } \\
\text { membantu meredakan demam. } \\
\text { 建 议 翻 译: Meredakan panas dalam dan demam, digunakan untuk mengatasi } \\
\quad \text { influenzah panas dingin/meriang, tubuh terasa letih, sakit kepala, }\end{array}$ \\
\hline
\end{tabular}




\begin{tabular}{|c|c|}
\hline & batuk, dan radang tenggorokan. \\
\hline 11 & $\begin{array}{l}\text { 天王补心丹 } \\
\text { 翻译问题: 减译 } \\
\text { 源语: 滋阴养血, 补心安神。用于心阴不足, 心悸健忘, 失眠多梦, 大便干燥。 } \\
\text { 译语: Membantu mengobati sulit tidur, pening kepala, dan perasaan tidak tenang. } \\
\text { 建 议翻 译 : Membantu memperlancar sirkulasi darah, menenangkan hati dan } \\
\quad \text { mengobati sulit tidur. Digunakan untuk orang yang jatung lemah, } \\
\quad \text { perasaan tidak tenang, pelupa, insomnia, banyak berkhayal, dan } \\
\text { gangguan pencernaan. }\end{array}$ \\
\hline 12 & $\begin{array}{l}\text { 月见草油胶丸 } \\
\text { 翻译问题: 减译 } \\
\text { 源语: 用于防治动脉硬化、降低血脂等。 } \\
\text { 译语: membantu megurangi lemak darah. } \\
\text { 建 议 翻 译 : Digunakan untuk mencegah penyempitan pembuluh darah, serta } \\
\quad \text { mengurangi lemak darah dan lain-lain. }\end{array}$ \\
\hline 13 & $\begin{array}{l}\text { 保济丸 } \\
\text { 翻译问题: 减译 } \\
\text { 源语: 疴呕肚痛、四时感冒、各种痧症、伤风咳嗽、气喘痰多、身热头痛、肠胃 } \\
\text { 各病、酒醉食滞、舟车军眩。 } \\
\text { 译 语 : Untuk meredakan demam, muntah, sakit perut, mabuk alkohol, serta } \\
\text { mengurangi frekuensi buangair besar dan memadatkan tinja. } \\
\text { 建议翻译: Untuk meredakan sakit perut, muntah, demam, berbagai penyakit akut, } \\
\text { batuk pilek, sulit bernafas, sakit kepala, gangguan pencernaan, mabuk } \\
\text { alkohol, serta mabuk kendaraan. }\end{array}$ \\
\hline 14 & $\begin{array}{l}\text { 癚药丸 } \\
\text { 翻译问题: 减译 } \\
\text { 源语: 夏令受暑霍乱转筋呕吐恶心绞肠痧症。 } \\
\text { 译语: Membantu meredakan masuk angin seperti perut kembung, mual, meriang. } \\
\text { 建 议翻 译: Membantu meredakan kolera (diare yang disebabkan bakteri), mual, } \\
\quad \text { muntah, fistula usus (cairan lambung bocor ke bagian usus). }\end{array}$ \\
\hline 15 & $\begin{array}{l}\text { 复方丹参片 } \\
\text { 翻译问题: 减译 } \\
\text { 功能: 活血化瘀, 芳香开窍, 理气止痛, 服用方便, 无副作用。 } \\
\text { 译语: Membantu memperbaiki sirkulasi darah. } \\
\text { 建 议翻 译 : Membantu memperbaiki sirkulasi darah, memperbaiki siklus chi dan } \\
\quad \text { meredakan rasa sakit, mudah dikonsumsi, tidak memiliki efek samping. }\end{array}$ \\
\hline 16 & $\begin{array}{l}\text { 海马补肾丸 } \\
\text { 翻译问题: 误译 }\end{array}$ \\
\hline
\end{tabular}




\begin{tabular}{|c|c|}
\hline & $\begin{array}{l}\text { 源语: 身体衰弱、气血两亏、肾气不足、面黄肌瘦、心跳气短、腰酸腿疼、 } \\
\text { 健忘虚喘。 } \\
\text { 译语: Membantu menjaga stamina dan memperlancar peredaran darah. } \\
\text { 建议翻译: Mengatasi fisik lemah, aliran darah dan chi tidak lancar, gangguan ginjal, } \\
\quad \text { tidak enak badan, jantung berdebar, nafas pendek, pinggang dan lutut } \\
\quad \text { sakit, pikun dan asma. }\end{array}$ \\
\hline 17 & $\begin{array}{l}\text { 筋骨跌伤丸 } \\
\text { 翻译问题: 误译 } \\
\text { 源语: 散㾉活血, 消肿止痛。 } \\
\text { 译语: Mengurangi pegal-pegal, linu-linu pada persendian dan mengendorkan otot } \\
\quad \text { yang kaku. } \\
\text { 建议翻译: Membantu melancarkan sirkulasi darah, meredakan bengkak dan sakit. }\end{array}$ \\
\hline 18 & $\begin{array}{l}\text { 天麻蜜环素 } \\
\text { 翻译问题: 增译 } \\
\text { 源语: 减轻头痛祛风止晕 } \\
\text { 译语: }- \text { Membantu meringankan sakit kepala. } \\
\quad \text {-Membantu memperbaiki sirkulasi darah. } \\
\text { 建 议翻 译: Membantu meredakan sakit kepala, menghilangkan masuk angin dan } \\
\quad \text { meredakan pusing. }\end{array}$ \\
\hline 19 & $\begin{array}{l}\text { 明目上清丸 } \\
\text { 翻译问题: 增译 } \\
\text { 源语: 清热散风, 明目止痛。用于暴发火眼。 } \\
\text { 译语: Membantu meredakan gejala masuk angin seperti perut kembung, mual dan } \\
\text { pusing. Membantu menyembukan mata yang merah, gatal-gatal dan } \\
\text { membengkak yang disebabkan panas dalam. } \\
\text { 建议翻译: Membantu meredakan demam dan masuk angin, mempertajam penglihatan } \\
\quad \text { dan meredakan sakit. Digunakan untuk mata merah dan gatal-gatal. }\end{array}$ \\
\hline
\end{tabular}

\section{Sinar Herba Radix 的药品建议翻译}

\begin{tabular}{|l|l|}
\hline 1 & $\begin{array}{l}\text { 熊胆跌打丸 } \\
\text { 翻译问题: 减译 }\end{array}$ \\
& \begin{tabular}{l} 
源语: 跌打损伤、筋骨扭伤、跌伤肿痛、淤血滞痛。 \\
译语: Membantu meringankan bengkak atau memar akibat keseleo. \\
建议翻译: Membantu meringankan luka akibat jatuh, sendi keseleo, bengkak akibat \\
\hline 2
\end{tabular} \\
\hline
\end{tabular}




\begin{tabular}{|c|c|}
\hline & $\begin{array}{l}\text { 翻译问题: 减译 } \\
\text { 源语: 凡因蒸汽、沸水、烈火、滚油、钢水或化学物质作用于身体或放射线及电 } \\
\text { 灼等所致的深浅各型的烧伤、棂伤, 敷用本品, 均有显著疗效。 } \\
\text { 译语: Mengobati luka bakar mengurangi rasa nyeri. } \\
\text { 建议翻译: Mengobati luka bakar yang disebabkan oleh air mendidih, air panas, api } \\
\quad \text { panas, minyak panas, atau bahan kimia dan lainnya. Apabila dipakai, } \\
\text { akan ada hasil yang menyembuhkan. }\end{array}$ \\
\hline 3 & $\begin{array}{l}\text { 月见草油 } \\
\text { 翻译问题: 减译 } \\
\text { 源语: 用于防治动脉硬化、降低血脂等。 } \\
\text { 译语: Untuk membantu mengurangi lemak tubuh. } \\
\text { 建议翻译: Digunakan untuk mencegah penyempitan pembuluh darah, serta membantu } \\
\quad \text { mengurangi lemah darah. }\end{array}$ \\
\hline 4 & $\begin{array}{l}\text { 燕窝虫草 } \\
\text { 翻译问题: 减译 } \\
\text { 源语: 润肺止咳、顺气除痰、止咳平喘、解燥利咽、平肝清热、生津解渴。 } \\
\text { 译语: Membantu meredakan batuk berdahak dan melegakan pernapasan. } \\
\text { 建议翻译: Membantu meredakan batuk berdahak, melegakan pernapasan, melegakan } \\
\text { tenggorokan, meredakan panas serta menghilangkan dahaga. }\end{array}$ \\
\hline 5 & $\begin{array}{l}\text { 补脑丸 } \\
\text { 翻译问题: 减译 } \\
\text { 源语: 滋补精血, 健脑益智, 安神镇惊, 化痰熄风, 用于迷惑健忘, 记忆减退, } \\
\text { 头晕耳鸣, 心烦失眠, 心悸不宁。 } \\
\text { 译语: Membantu meringankan gangguan sulit tidur. } \\
\text { 建 议翻 译 : Membantu memperbaiki sirkulasi darah, menyehatkan fungsi otak, } \\
\quad \text { meningkatkan kecerdasan, membantu meringankan gangguan sulit tidur } \\
\quad \text { dan sakit kepala. Digunakan untuk orang yang kebingungan, pelupa, daya } \\
\text { ingat lemah, pusing dan telinga berdenging, insomnia, serta perasaan } \\
\quad \text { gelisah. }\end{array}$ \\
\hline 6 & $\begin{array}{l}\text { 人参再造丸 } \\
\text { 翻译问题: 减译 } \\
\text { 源语: 祛风化病, 活血通络。用于中风, 步履艰难, 口眼歪斜, 手足痉挛, 左㿈 } \\
\text { 有疾, 筋骨疼痛, 半身不遂, 言语不清。 } \\
\text { 译语: Membantu meredakan nyeri sendi. } \\
\text { 建议翻译: Membantu menghilangkan angin dan dahak, serta membantu melancarkan } \\
\text { sirkulasi darah. Digunakan untuk penderita stroke, kesulitan bergerak, } \\
\quad \text { muka dan mulut miring sebelah, mati rasa, nyeri pada persendian, sulit } \\
\text { menggerakkan anggota badan, serta kesulitan berbicara. }\end{array}$ \\
\hline
\end{tabular}




\begin{tabular}{|c|c|}
\hline 7 & $\begin{array}{l}\text { 肿瘤消癌丸 } \\
\text { 翻译问题: 症译 } \\
\text { 源语: 增强身体抵抗力预防癌病。此方对血管肿瘤、胃癌、直肠癌、肝癌、卵巢 } \\
\text { 肿瘤、子宫癌、支气管癌、肺癌, 极有效。 } \\
\text { 译语: Membantu memelihara kondisi kesehatan pada penderita kanker. } \\
\text { 建议翻 译: Membantu menguatkan daya tahan tubuh untuk mencegah kanker. Ini } \\
\text { berkhasiat terhadap kanker pembuluh darah, kanker lambung, kanker } \\
\text { rektrum (dubur), kanker hati (liver), kanker ovarium (kista), kanker } \\
\text { uterus (rahim), bronchitis (saluran paru-paru), dan kanker paru-paru. }\end{array}$ \\
\hline 8 & 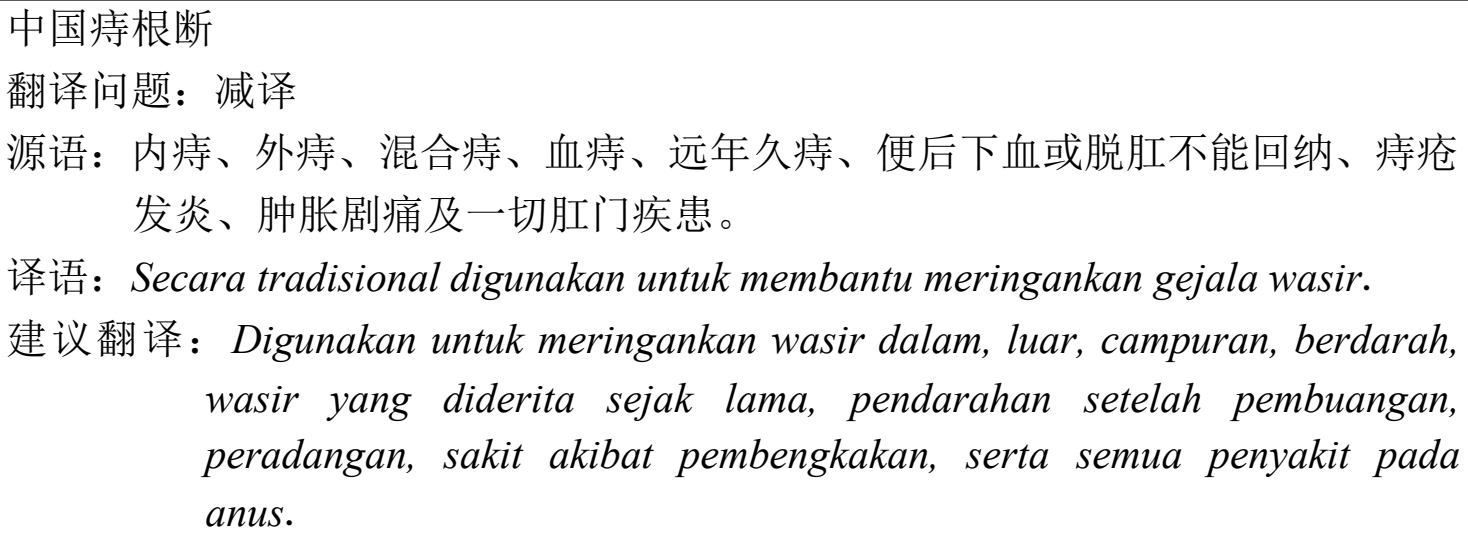 \\
\hline 9 & $\begin{array}{l}\text { 三花减肥丸 } \\
\text { 翻译问题: 减译 } \\
\text { 源语: 适当控制饮食、少食高脂肪及寒湿之品。 } \\
\text { 译语: Membantu mengurangi lemak dalam tubuh dan menurunkan berat badan. } \\
\text { 建议翻译: Membantu mengontrol nafsu makan, makanan yang mengandung tinggi } \\
\quad \text { lemak serta makanan dingin dan berlembab. }\end{array}$ \\
\hline 10 & $\begin{array}{l}\text { 痔疮膏 } \\
\text { 翻译问题: 误译 } \\
\text { 源语: 清热解毒, 消炎止痛, 杀虫。 } \\
\text { 译语: Membantu meringankan gejala wasir. } \\
\text { 建议翻译: Membantu meredakan demam, mengurangi peradangan dan rasa sakit, } \\
\qquad \begin{array}{l}\text { dan membasmi insektisida. }\end{array}\end{array}$ \\
\hline 11 & $\begin{array}{l}\text { 田七增高丸 } \\
\text { 翻译问题: 误译 } \\
\text { 源语: 对小儿先天禀赋不足、胎孕期受损、后天发育不良、身材矮小等症。 } \\
\text { 译语: Membantu memelihara kesehatan dan memperbaiki sirkulasi darah. } \\
\text { 建议翻译: Digunakan untuk anak yang kecerdasannya kurang, mengalami masalah } \\
\text { pada saat dalam kandungan, pertumbuhannya terganggu, badan pendek } \\
\text { dan lainnya. }\end{array}$ \\
\hline 12 & 冬凌草片 \\
\hline
\end{tabular}




\begin{tabular}{|c|c|}
\hline & $\begin{array}{l}\text { 翻译问题: 误译 } \\
\text { 源语: 清热消肿。用于急慢性扁桃体炎、咽炎、喉炎、口腔炎、试用于抗癌。 } \\
\text { 译语: Membantu meredakan tenggorokan kering. } \\
\text { 建议翻译: Meredakan panas dalam dan pembengkakan. Digunakan untuk orang yang } \\
\quad \text { mengalami peradangan pada amandel, tenggorokan, tenggorokan akut, } \\
\quad \text { luka dalam mulut dan gusi, serta mencegah kanker. }\end{array}$ \\
\hline 13 & $\begin{array}{l}\text { 强力银尧片 } \\
\text { 翻译问题: 增译 } \\
\text { 源语: 清热解毒、辛凉、解表。 } \\
\text { 译语: Membantu meredakan demam, pilek, dan sakit tenggorokan. } \\
\text { 建议翻译: Membantu meredakan demam, mengatasi influenza, dan keringat dingin. }\end{array}$ \\
\hline 14 & $\begin{array}{l}\text { 冬虫夏草 } \\
\text { 翻译问题: 误译 } \\
\text { 源语功能: 补虚损、益精气、补肺益肾、止咳化痰。 } \\
\text { 源语主治: 慢性气管炎、支气管哮喘、肝硬化及体弱多病。 } \\
\text { 译语: Membantu menjaga kesehatan badan. } \\
\text { 建议翻译: Membantu menjaga kesehatan badan, meningkatkan vitalitas dan energi } \\
\text { tubuh, memperkuat paru-paru, meredakan batuk dan sesak. Digunakan } \\
\text { untuk mengobati radang paru-paru kronis, sirosis (pengerasan hati) dan } \\
\text { tubuh yang lemah yang mudah terserang penyakit. }\end{array}$ \\
\hline
\end{tabular}

\section{四结论}

中成药功效语是个特别重要的部分, 尤其对药品本身的功效, 因此能够正确地翻 译药品的功效语有助于提高消费者对药品更加了解药品的信息以及更加相信次要的功 效，也会率提高药品的使用率这样会影响公司的销售率。

笔者发现在翻译功效语中存在着三大问题，即减译问题、增译问题和误译问题， 减译问题占 $63.8 \%$, 因此不建议使用减译来翻译功效语。笔者认为应该使用直译来翻译 功效语。此外译员在翻译之前首先必须懂功效语内容与作用。因为这也是对消费者一 种责任。

\section{参考文献}

[1] 熊文华. 翻译方法和技巧 $[\mathrm{J}]$. 翻译 $\mathrm{T}$ 形台, 2007.

[2] 熊兵. 翻译研究中的概念混淆 一 以 “翻译策略”、“翻译方法” 和 “翻译技巧” 为列 $[\mathrm{J}]$. 华中师范大学, 2014 . 
[3] 穆雷, 邹兵. 翻译的定义及理论研究: 现状、问题与思考 $[\mathrm{J}]$. 广东外语外贸大学, 2015.

[4] 张雷, 云红. 中药说明书药名、功效语及结构词英译研究 $[\mathrm{J}]$. 外语教育研究, 2018 .

[5] 蓝玉婷. 中药翻译文本中的翻译错误分析 $[\mathrm{J}]$. 苏北大学中文系, 2018 .

[6] 李萍风. 中药说明书翻译中存在的问题与技巧应用 $[\mathrm{J}]$. 江西中医药大学， 2014 .

[7] 邓永志，董云龙. 中成药临床应用指导原则 $[\mathrm{J}]$. 国中医药医函，2010，3.

[8] 郑鸿翔, 张斌. 中药功效术语英译的常见问题与技巧 $[\mathrm{J}]$. 南京中医药大学外国语 学院, 2016.

[9] 杨哲. 从功能对等角度论药品说明书的翻译 $[\mathrm{J}]$. 东北师范大学， 2009 .

[10］李淑杰. 目的论三法则与药品说明书的翻译 $[\mathrm{J}]$. 辽宁工业大学, 2008 .

[11] 金锐. 中成药重复用药研究专题 $[\mathrm{J}]$. 中南药学, 2016 .

[12］蒋林. 中药名及其功效语的汉英翻译 $[\mathrm{J}]$. 广东韶关学院外语系， 2002 .

[13］罗海燕. 功能主义翻译理论关照下的中药说明书的翻译 $[\mathrm{J}]$. 南京中医药大学, 2009.

[14] Muchtar, Muhizar. Penerjemahan[J]. Medan: Bartong Jaya, 2011.

[15] Newmark, Peter. A Textbook of Translation[J]. U.K.: Prentice Hall International Ltd, 1988.

Catatan:

Artikel pernah dipresentasikan pada Seminar Nasional APSMI 24 Oktober 2020 